OPEN ACCESS

Edited by:

Erik Cordes,

Temple University, United States

Reviewed by:

Andrea Gori,

University of Barcelona, Spain

Michael Vecchione,

National Oceanic and Atmospheric Administration (NOAA), United States

Katleen Robert,

Memorial University of Newfoundland,

Canada

${ }^{*}$ Correspondence:

J. K. M. Appah

john.appah@ucc.ie

Specialty section

This article was submitted to

Deep-Sea Environments and Ecology,

a section of the journal

Frontiers in Marine Science

Received: 11 June 2020 Accepted: 09 September 2020 Published: 06 October 2020

Citation:

Appah JKM, Lim A, Harris K,

O'Riordan $R$, O'Reilly $L$ and

Wheeler AJ (2020) Are Non-reef

Habitats as Important to Benthic

Diversity and Composition as Coral

Reef and Rubble Habitats

in Submarine Canyons? Analysis of Controls on Benthic Megafauna Distribution in the Porcupine Bank

Canyon, NE Atlantic.

Front. Mar. Sci. 7:571820.

doi: 10.3389/fmars.2020.571820

\section{Are Non-reef Habitats as Important to Benthic Diversity and Composition as Coral Reef and Rubble Habitats in Submarine Canyons? Analysis of Controls on Benthic Megafauna Distribution in the Porcupine Bank Canyon, NE Atlantic}

\author{
J. K. M. Appah' ${ }^{1 *}$, A. Lim', K. Harris', R. O'Riordan', L. O’Reilly' and A. J. Wheeler',2 \\ ${ }^{1}$ School of Biological, Earth and Environmental Sciences/Environmental Research Institute, University College Cork, Cork, \\ Ireland, ${ }^{2}$ Irish Centre for Research in Applied Geosciences/Marine and Renewable Energy Institute, University College Cork, \\ Cork, Ireland
}

Submarine canyons support high biomass communities as they act as conduits where sediments, nutrients, and organic matter from continental shelves, or those that are carried along by slope currents, are transported into the abyssal zone. The Porcupine Bank Canyon (PBC), located on the Irish continental margin and isolated from terrigenous inputs, reveals a complex terrain and substrate variation that affect the distribution of benthic fauna. Here, ROV-based benthic video, conductivity-temperaturedepth (CTD), current velocity profiles, suspended particulate organic matter (POM) and bathymetric data were assessed to determine the controls on the distribution of benthic megafauna throughout the canyon. Multivariate analysis of the benthic community reveals significant differences in community structure among habitats and site locations throughout the canyon. Furthermore, these results show that non-reef habitats exhibit more variation in the composition of benthic taxa than coral reef and rubble habitats, with the following species contributing most to the structural differentiation between habitats: Leiopathes glaberrima (12.46\%), Hexadella dedritifera (10.37\%), Cidaris cidaris (9.31\%), Aphrocallistes beatrix (9.33\%), Araeosoma fenestratum (9.11\%), Stichopathes cf. abyssicola (7.39\%), Anthomastus grandiflorus (4.66\%), and Benthogone rosea (3.84\%). In addition, greater diversity, taxa evenness and high abundance of motile fauna were observed in non-reef habitat and the canyon flank. Seabed terrain features (depth, slope) are the most important environmental drivers that affect benthic taxa distribution while site locations and habitat type are the categorical variables that influence taxa distribution in the PBC. The highest mean current speed was observed on the canyon flank where the highest Shannon's diversity was recorded while mean current speed ranged from 18.2-31.3 $\mathrm{cm} \mathrm{s}^{-1}$. As the PBC is cut off from direct terrigenous input, this research contributes to understanding cold-water coral habitat responses to natural 
Northeast Atlantic environmental conditions. The findings of the current study will inform key stakeholders on how to responsibly interact with the canyon benthic habitats and can help inform policy makers on the effective conservation and management of the cold-water coral habitat in the PBC and other canyons.

Keywords: biodiversity, Porcupine Bank Canyon, POM, cold-water coral, non-reef habitat, species distribution, habitat variability

\section{INTRODUCTION}

Submarine canyons are geomorphic features incised into continental margins and shelves (Shepard, 1972; Harris and Whiteway, 2011; Harris et al., 2013; Puig et al., 2014), including slopes of oceanic Islands (Vetter et al., 2010). They can be connected to landward river systems (Huang et al., 2014), terrestrially disconnected or tectonically controlled (Greene et al., 1991; Liu et al., 1993; Lo Iacono et al., 2014). Canyons have complex topographies and morphologies that affect hydrographic, oceanographic and biological processes (Allen et al., 2001; Bosley et al., 2004; Trotter et al., 2019). They are conduits for organic matter, nutrients and sediment transport to the abyssal zone (de Stigter et al., 2007; Kiriakoulakis et al., 2011; Mazzini et al., 2012; Puig et al., 2013) as well as litter and organic pollutants (de Jesus Mendes et al., 2011; Mordecai et al., 2011; Schlining et al., 2013; Tubau et al., 2015). Storm events may also affect circulation and current regimes along the rims of submarine canyons (Shan et al., 2014).

Sedimentation processes in submarine canyons can affect the distribution of the benthic community through increased disturbance and modified turbidity (Martín et al., 2014; Huvenne and Davies, 2014) with hydrographic and oceanographic processes affecting food supply (Canals et al., 2006; Kenchington et al., 2014) which in turn affects benthic community structure (Kiriakoulakis et al., 2007; De Leo et al., 2010).

Seabed terrain and substrate variation provide a variety of suitable habitats for benthic communities in submarine canyons (Schlacher et al., 2007; McClain and Barry, 2010; De Mol et al., 2011; Cunha et al., 2011; Paterson et al., 2011; Vetter et al., 2010; Davies et al., 2014; Fanelli et al., 2018) with submarine canyons recognized as areas of significant ecological importance. They are considered 'hotspots' for biodiversity (De Leo et al., 2010; Vetter et al., 2010; Cunha et al., 2011; Martín et al., 2011; Puig et al., 2013, 2014) and are able to support coldwater coral ecosystems (Orejas et al., 2009; Huvenne et al., 2011; Morris et al., 2013; Khripounoff et al., 2014; van den Beld et al., 2017; Aymà et al., 2019; Puig and Gili, 2019), with which can be associated more than 1,300 species (Roberts et al., 2006; Henry and Roberts, 2015). In particular, Lophelia pertusa (syn. Desmophllum pertusum: Addamo et al., 2016; taxonomic status pending scientific community consensus) reefs are able to form geologic features called coral mounds on the interfluves of submarine canyons (De Mol et al., 2011; Stewart et al., 2014). Coral mounds can be tens of meters tall and several kilometers wide (Wheeler et al., 2007) and are capable of affecting local hydrographic processes (Mienis et al., 2007). It has also been noted that cold-water corals show slow growth and recovery after anthropogenic disturbance (Fabri et al., 2014; Huvenne et al., 2016).

The Porcupine Bank Canyon (PBC) is incised into the western margin of the Porcupine Bank, $300 \mathrm{~km}$ west of Ireland (Figure 1; Dorschel et al., 2010) and is cut off from direct terrestrial inputs, making it an ideal model to investigate oceanographic influences on coral habitats in the Northeast Atlantic. It is situated between the Porcupine Seabight to the southeast and the Rockall Trough to the west into which the canyon drains. The PBC is tectonically controlled (Shannon, 1991, Shannon et al., 2007) and is the largest submarine canyon on Ireland's western margin (63 km in length) and incises higher up into the Porcupine Bank than neighboring canyons, to $420 \mathrm{~m}$ water depth crossing the cold-water coral habitable zone (Davies et al., 2008). Elsewhere on the Porcupine Bank, cold-water coral reefs are located upslope of canyon heads on the open margin (Akhmetzanov et al., 2003; van Weering et al., 2003; Wheeler et al., 2005; Dorschel et al., 2009). The PBC is a geological feature that can be described as an area of high habitat heterogeneity that supports a high biomass (Wheeler and Shipboard Party, 2017; Lim and Shipboard Party, 2018). It has been designated as a Special Area of Conservation (SAC; Supplementary Figure S1) under the EU Habitat Directive (92/43/EEC) as a submarine canyon with cold-water corals and closed to fishing. L. pertusa is the main framework-forming cold-water coral in the canyon. The slow growth rate of this sclerectinian coral (Orejas et al., 2008; Gass and Roberts, 2006) demands that the ecosystems in canyons be managed and protected in the face of continued anthropogenic activities such as trawl fishing. To this effect, the present study investigated: (a) the benthic megafauna distribution and variability within site locations and habitats, and (b) the environmental drivers of the benthic faunal distribution and variability in the PBC. These questions are addressed using a rich dataset (including $46.81 \mathrm{~km}$ of HD ROV video data), characterizing megafauna distribution in the $\mathrm{PBC}$ for the first time. Due to the isolation of this major submarine canyon on the European Atlantic margin, the relationships discovered here act as a "natural barometer" for oceanic controls of benthic diversity in submarine canyons including for cold-water corals.

\section{MATERIALS AND METHODS}

Survey, oceanographic and sample data from the PBC (Supplementary Table S1 and Figure 1) were collected on 


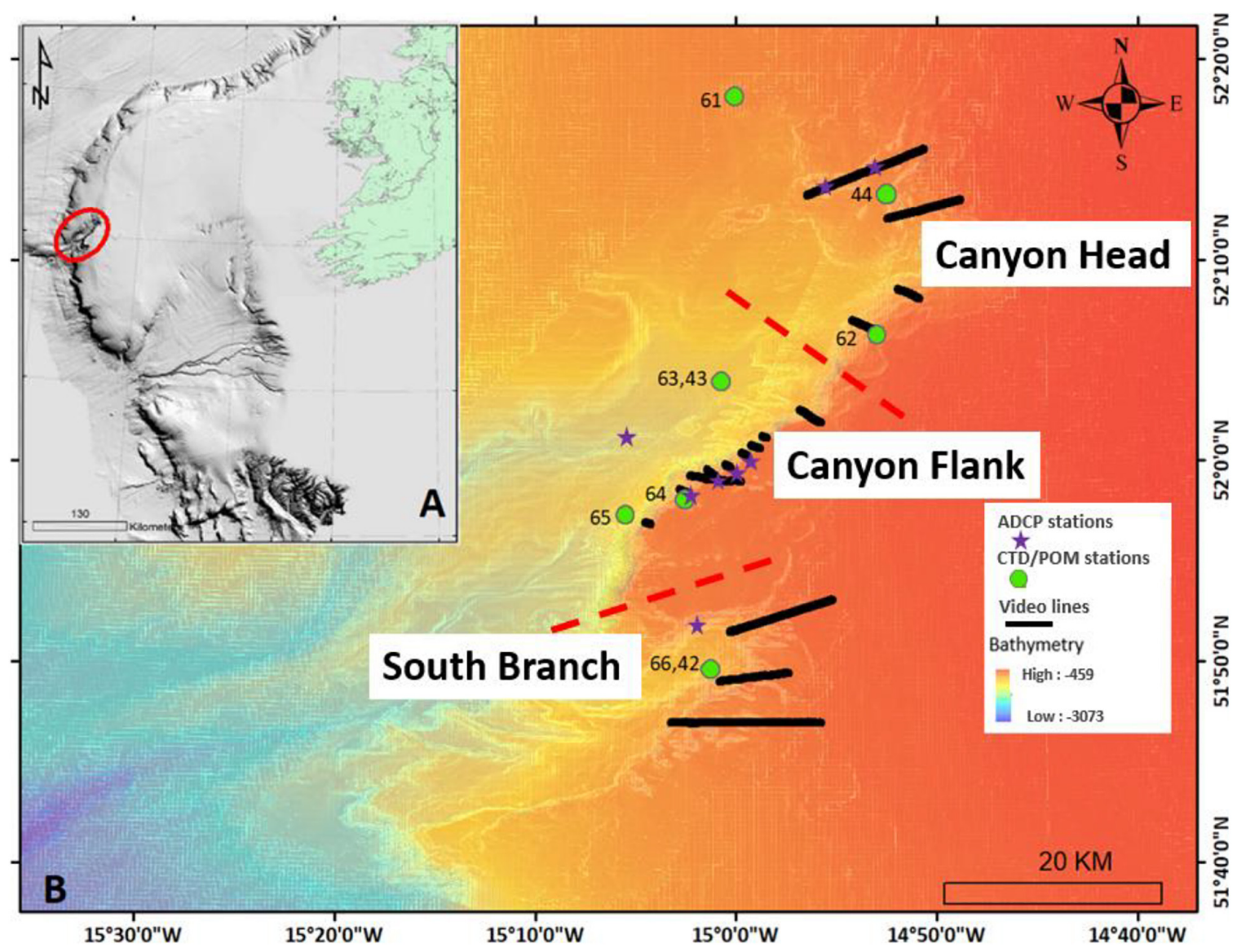

FIGURE 1 | Map showing the location of (A) the Porcupine Bank Canyon (PBC; red ellipse) on the Irish-Atlantic margin, (B) acoustic doppler current profiler (ADCP) stations, conductivity-temperature-depth (CTD)/particulate organic matter (POM) stations, benthic video lines and ship-based MBES bathymetry. Different site locations of the canyon are separated by red broken lines.

board the RV Celtic Explorer with the Holland I ROV ${ }^{1}$ in 2017 (CoCoHaCa I: Wheeler and Shipboard Party, 2017) 2018 (CoCoHaCa II: Lim and Shipboard Party, 2018), and 2019 (MoCha_Scan I: Lim and Shipboard Party, 2019). The ROV (made by Soil Machine Dynamics Limited) was equipped with two 400 Watt Deep-sea Power and Light SeaArc2 Hydrargyrum Medium-Arc Iodide (HMI) lights, two 25,000 lumen Cathx Ocean APHOS LED lights, a pair of Deep-sea Power and Light lasers $10 \mathrm{~cm}$ apart, an Insite Mini Zeus forward-facing high definition (HD; 1080p) video camera and a Kongsberg 14-208 digital stills tilt camera systems to collect benthic video data at a speed of 0.2 knots. Remotely operated vehicle (ROV) navigation was recorded with a coupled Sonardyne Ranger 2 USBL (ultra-short baseline positioning system) and RD Instruments workhouse doppler velocity logger.

\section{Seabed Terrain and Substrata Characterization}

Ship-based $30 \mathrm{kHz}$ multibeam echosounder (EM302) data were acquired using parallel sets of lines following depth

\footnotetext{
${ }^{1}$ www.marine.ie
}

contours over the canyon, and gridded at $25 \mathrm{~m}$ resolution. The minimum swath overlap was $25 \%$ at c. 8 knot and swath width was $2,000 \mathrm{~m}$. The acquired data were managed and processed with Seafloor Information System, cleaned with Fledermaus Qimera and tidal corrections were applied. A sound velocity probe was applied to the data to correct it for water sound velocity variations. The data were imported into ArcMap v10.4 and projected in UTM zone 28N. A total area of $1,800 \mathrm{~km}^{2}$ of seabed was surveyed. Terrain variables (slope, aspect, and rugosity) were obtained using ESRI's Spatial Analyst Extension Tool in ArcMap, and values were extracted using the extract values to points tool incorporated in ArcMap. According to Guinan et al. (2009), slope is "a plane tangent to a digital terrain model surface at the center of an analysis window" while aspect is "the azimuthal direction of the steepest slope at the center of the analysis window." Rugosity is defined as "the ratio of surface area to planar area" (Jenness, 2002). Aspect was transformed into two variables namely northness and eastness in MS Excel. First, aspect was converted into radians $\left(\pi *^{\left.\operatorname{aspect}\left({ }^{\circ}\right) / 180\right)}\right.$ and then converted into northness (cosine of aspect in rad) and eastness (sine of aspect in $\mathrm{rad}$ ) to provide a continuous 
measure from negative one to positive one. Vertical and oblique imagery were used to characterize the seabed as adopted in Mortensen and Buhl-Mortensen (2004); Vertino et al. (2010), and Lim et al. $(2017,2018)$. In total 1,823 images were used to characterize the different seabed types in the PBC. A gridded quadrat of $0.25 \mathrm{~m}^{2}$ (with 25 individual squares) created based on the $10 \mathrm{~cm}$ laser scale was overlaid on each image, and the percentage cover was estimated as the ratio of grids overlying a seabed type to the total number of grids in the grid quadrat. The point count method (applied in the present study) for estimating the percentage cover of a seabed type yields accurate results (Mortensen and Buhl-Mortensen, 2004). Five substrata were identified (Supplementary Tables S2,S3), and resolved into coral reef and rubble (dead/live corals and coral rubble) and non-reef habitats (sediment dominated, sediment, and dropstone and bedrock; Supplementary Table S3) at each of the three site locations in the canyon (Figure 1). Live/dead coral is characterized by a cell coverage of $>50 \%$ observable living and dead parts while coral rubble is dominated by a cell coverage of $>60 \%$ observable biogenic materials. Hermatypic corals and ahermatypic coral polyps are biological organisms which are able to build coral reefs (physical features or habitats made from secretions of calcium carbonate and other associated biological and non-biological materials). Therefore coral presence was determined when the coral polyp's corallite skeletal casing (usually bright, white or orange in color in the NE Atlantic) was easily noticeable while dead coral was identified as darker, gray or brown skeleton. Smaller fragments of dead skeleton were identified as coral rubble.

\section{Megafaunal Analysis}

A series of regularly spaced, but randomly located, ROV-video transects from the deep-waters to the shallow-waters in the PBC were run to cover the different substrata and habitats throughout the canyon. ROV-based video frames were extracted at $60 \mathrm{~s}$ intervals using the online software Free Video to JPG converter available from DVDVideoSoft. Poor quality images and those captured at sub-optimal angles were removed. The survey depth ranged between $582-2,126 \mathrm{~m}$ from the canyon head to the south of the canyon traversing the canyon slope. As described for the seabed terrain and substrata characterization, a gridded quadrat of $0.25 \mathrm{~m}^{2}$ was created based on a $10 \mathrm{~cm}$ laser scale and overlaid on each image. The abundance of benthic taxa was estimated following Doyle et al. (2005) and Boolukos et al. (2019). Colonial taxa (e.g., Hexadella dedritifera, Parantipathes sp. and Leiopathes glaberrima) were estimated as percentage cover while discrete organisms (e.g., Asteroidea species, squat crab and Chaecon affinis) were counted. The percentage cover was estimated as the ratio of grids overlying a taxon to the total number of grids in the grid quadrat. However, the hit point method (Doyle et al., 2005) was used to estimate the percentage cover of colonial taxa in the present study. With the hit point method, a point of intersection is made in each of the 25 grids by joining the four vertices in each grid with two straight diagonal lines. An organism is counted if the point of intersection touches it, and the process is repeated for each of the quadrats in particular habitat (coral reef and rubble - non-reef) or location (flank - head - south). The percentage cover then is the ratio of the number of hits of a taxon to the total number of possible hits multiplied by 100 . All the images used to characterize the seabed types were used to characterize the benthic fauna. The density (i.e., individuals $\mathrm{m}^{-2}$ ) of discrete taxa was determined by multiplying the mean number of each taxon (within $\mathrm{N}$ number of $0.25 \mathrm{~m}^{2}$ grid quadrat) by four. Individual organisms were taxonomically resolved to species level where possible although this was not achievable for most taxa, given the limitations associated with identifying benthic organisms from ROV-images. As such, many organisms were identified as morphotypes or species, using best practice for habitat analysis (Henry and Roberts, 2013; Henry et al., 2014).

\section{Statistics}

Most of the survey data were analyzed with $R$ ( $R$ Core Development Team, 2014). Shannon's diversity $\left(\mathrm{H}^{\prime} ; H^{\prime}=-\sum_{i=1}^{S} P i \ln P i\right.$ Shannon, 1948) and Pielou's evenness $\left(J^{\prime}=H^{\prime} / \ln S\right)$ (Pielou, 1966) were estimated for the studied habitats (coral - non-reef) and locations in the canyon (flank head - south). $P i$ is the proportion of the $i$ th taxa while $S$ is the total number of taxa within each community. Pielou's index evaluates the relative abundance of the benthic taxa (species evenness) while Shannon's index calculates the diversity of the community, considering the relative abundance of each taxon. Significant differences between taxa evenness and Shannon's diversity index for the variable habitats and site locations were evaluated using $z$-test. $Z$-test is less conservative than Student's $t$ test and can be used when the population variance is known or unknown, but the sample size is large (Derrick et al., 2015). The $z$-test could also be used when the population is normally distributed. It is worthy to note that Geary's $C$ test (for spatial autocorrelation; Bivand et al., 2008; Dubé and Legros, 2014) estimates a $z$-value (by randomization or normalization). Also, a Bonferroni correction was applied to assess significance of the taxa evenness and Shannon's diversity among site locations throughout the PBC. L. pertusa data were excluded from the diversity indices since it is the main framework-forming coral and occurs everywhere in the canyon. L. pertusa percentage cover was, however, estimated for the three site locations existing within the canyon. Significant differences between $L$. pertusa percentage cover in each of the three site locations within the $\mathrm{PBC}$ were determined by performing a pairwise $z$-test as there were only three levels for site locations. A $z$-test is suitable for testing proportional data and data from a large sample size (Krishnamoorthy and Thomson, 2002). Preliminary test of spatial autocorrelation of sample points among habitats and site locations by randomized Geary's $C$ test was made in ROOKCASE (Sawada, 1999). Rarefaction curves were made to standardize the sample size (on each substrate, habitat, and site location; Fussey, 1995; Belgrano and Reiss, 2011). Rarefaction curves were made in PAST ver 2.17c (Hammer et al., 2001).

Presence/absence data of the benthic taxa were used for multivariate analyses and again $L$. pertusa data were excluded in the analyses since, as previously mentioned, this species occurs everywhere in the canyon and is the main framework-forming 
coral. All sample points without data were removed, leaving 799 sample points for the multivariate analyses. Multivariate analyses were performed using the vegan package incorporated in R. BrayCurtis dissimilarity distance was estimated and used to perform analysis of similarity (ANOSIM), similarity of percentages (SIMPER) and non-metric multidimensional scaling (nMDS) ordination (Oksanen, 2011). The nMDS plot was made using the metaMDS function and the stress (measure of goodnessof-fit) calculated. Significant differences in the dissimilarities between the benthic taxa grouped into habitats and site locations were evaluated using the function adonis. nMDS scores $(x, y$ coordinates) were extracted and put into a new data frame. Lastly, employing the ggplot2 package, an aesthetic nMDS plot was made from the extracted nMDS scores. ANOSIM estimates significant differences in community structure. Also, ANOSIM is a method in vegan which can handle only class predictors and is less robust than adonis while adonis on the other hand is a function that partitions dissimilarities for the sources of variation, and uses permutation tests to examine the significances of those partitions (Oksanen et al., 2014). SIMPER analysis computes the taxa that most contribute to the observed differences in taxa composition. nMDS ordination is a rank-based approach which allows dissimilarities between objects to be viewed in reduced dimensional space. The stress value $(<0.2$ indicates a good representation) indicates a measure for the goodness-of-fit of the ordination (Clarke and Gorley, 2001; Clarke and Warwick, 2001).

Furthermore, canonical correspondence analysis (CCA) was used to determine the relationship between seabed terrain features (depth, slope, rugosity, and aspect), habitats, site locations and the distribution of the benthic taxa. CCA accounts for the patterns of taxa distribution by estimating taxa centroids (Ter Braak, 1986; Quattrini et al., 2012). The analyses were made employing the cca function of the vegan package incorporated in $\mathrm{R}$ (Oksanen et al., 2014). In order to perform CCA, sample points with no taxa were excluded from the analysis. Model choice was made by calculating the Akaike's information criterion (AIC; which is based on the measure of goodness-offit) using the step function. Also, the ordistep function which incorporates a random component in the model choice was run. In addition, the variance inflation factor (VIF) which determines multicollinearity amongst variables was estimated. A VIF of 1 indicates complete independence of variables while a VIF $>10$ indicates high multicollinearity. A permutation test was performed to determine the significance of the overall CCA model. Similar permutation tests were run to determine the significance of the environmental variables and the axes that explain the variability in the species distribution.

\section{Ecological Composition}

The benthic fauna were classified into functional groups, motility and mode of feeding. The benthic fauna were classified into functional groups based on their biological and life strategies (Jonsson et al., 2004; Henry and Roberts, 2007; Macdonald et al., 2010). Presence/absence data were used to estimate the percentage composition of functional groups within the variable habitats and site locations in the PBC. Motility comprised of motile and sessile taxa while mode of feeding consisted of suspension/filter feeder and detritivores (Macdonald et al., 2010;
Massironi, 2016). Also, the percentage composition of predators and non-predators were determined for the different habitats and site locations (Scharf et al., 2006; Bell, 2012; Thiel and Watling, 2015). Some of the benthic fauna identified exhibit more than one mode of feeding. As such, the present study focused mainly on predators, suspension/filter feeders and detritivores to observe possible trends of distribution.

\section{Environmental Context}

During summer months of 2018 and 2019, a conductivitytemperature-depth system (CTD; Sea-Bird 911 plus) was used to characterize the watermasses around the benthic habitats throughout the canyon (Supplementary Table S4 and Figure 1). Seawater samples were collected at different depths from 20$500 \mathrm{~m}$ above the seabed within the benthic boundary layer (McCave et al., 2001; Lueck et al., 2009) reflecting the dynamic sedimentary (organic and inorganic) processes that occur in the bottom and intermediate seawaters. A 101 Niskin bottle rosette unit on the CTD system was used to collect water samples at different depths at different stations and particulate organic matter (POM) data were determined via an ashing method, outlined in Strickland and Parsons (1972) and Lysiak-Pastuszak and Krysell (2004). In addition, eight $1 \mathrm{~Hz}$ Nortek Aquadopp acoustic doppler current profilers (ADCPs), were deployed in different macrohabitat types throughout the canyon (Figure 1). Each ADCP was vertically mounted (upward-facing) onto metal frames ('landers') to ensure they did not move. The $\mathrm{AD}$ once deployed (15-19/05/2019), continuously collected data (25 m above the transducer for a period of $1 \mathrm{~min}$ every $10 \mathrm{~min}$ ) for a period of approx. 2.5 months (retrieved on 27-28/07/2020).

\section{RESULTS}

\section{Seabed Terrain and Substrata}

Forty-eight percent of the observed seabed was classified as sediment dominated, $37 \%$ was coral rubble and the rest of the classifications were less than $10 \%$ (Table 1). Coral reef and rubble habitat comprised $91 \%$ coral rubble and $9 \%$ live/dead coral while non-reef habitat comprised 79\% sediment, $13 \%$ bedrock, and $8 \%$ sediment and dropstone (Table 1). Percent composition of sediment was highest on the canyon head while coral rubble was highest on the flank (Table 1). Twenty-five percent of bedrock was exposed in the flank but there was no exposed bedrock in the south (Table 1). Seabed terrain variables (depth, slope, rugosity, and aspect), the different habitats and site locations are presented in Supplementary Table S3.

\section{Benthic Taxa Composition}

A total of 60 benthic taxa from four different phyla were observed in the total survey area in the PBC. Examples of benthic fauna identified in the PBC are shown in Supplementary Figures S2, S3, S4. The four phyla occurred in the order: Cnidaria (50.8\%) > Echinodermata $(23.7 \%)>$ Porifera $(15.3 \%)>$ Mollusca $(10.2 \%)$, of the $0.25 \mathrm{~m}^{2}$ gridded quadrats. In addition, the percentage composition of the different phyla distributed in the different habitats and site locations within the canyon were estimated (Table 2). 
TABLE 1 | Percentage composition of the five substrata in the different habitats and site locations in the Porcupine Bank Canyon (PBC).

\begin{tabular}{|c|c|c|c|c|c|c|}
\hline \multirow[t]{2}{*}{ Substrata } & \multicolumn{6}{|c|}{ Percentage (\%) composition } \\
\hline & PBC & Coral reef and rubble habitat & Non-reef habitat & Flank & Head & South \\
\hline Bedrock (B) & 7.70 & 0.00 & 12.90 & 24.70 & 0.70 & 0.00 \\
\hline Dead/Live coral (DL) & 3.60 & 8.90 & 0.00 & 2.30 & 1.60 & 6.40 \\
\hline Coral rubble (R) & 36.50 & 91.10 & 0.00 & 42.00 & 26.60 & 41.20 \\
\hline Sediment (S) & 47.60 & 0.00 & 79.40 & 28.60 & 64.50 & 47.70 \\
\hline Sediment and dropstone (SD) & 4.60 & 0.00 & 7.70 & 2.30 & 6.50 & 4.70 \\
\hline
\end{tabular}

TABLE 2 | Percent composition of each of four phyla on the different habitats and site locations in the Porcupine Bank Canyon (PBC).

Habitat and site locations

Percentage (\%) composition

\begin{tabular}{|c|c|c|c|c|}
\hline & \\
\hline & Cnidaria & Echinodermata & Mollusca & Porifera \\
\hline Coral reef and rubble habitat & 53.659 & 17.073 & 9.756 & 19.512 \\
\hline Non-reef habitat & 56.863 & 25.490 & 7.843 & 9.804 \\
\hline Flank & 52.273 & 25.000 & 13.636 & 9.091 \\
\hline Head & 51.282 & 25.641 & 5.128 & 17.949 \\
\hline South & 55.172 & 17.241 & 6.897 & 20.690 \\
\hline
\end{tabular}

Mean percentage cover of benthic colonial taxa on coral reef and rubble habitat was four times greater than the mean percentage cover on non-reef habitat (Table 3). The glass sponges $\mathrm{H}$. dedritifera (26\%) and Aphrocallistes beatrix (27\%) and the black coral L. glaberrima (17\%) were the most common and dominant colonial species in the coral reef and rubble habitat while the echinoderm Cidaris cidaris (73\%) was the most common discrete species in the coral reef and rubble habitat. However, taxa distribution in nonreef habitat exhibited low dominance as the most common discrete taxa abundances were the echinoderms Araeosoma fenestratum (27\%), C. cidaris (26\%), Psolus squamatus (16\%) including the holothurian Benthogone rosea (21\%) while highest abundances of common colonial taxa were L. glaberrima (19\%) and Stichopathes cf. abyssicola (16\%). The percentages of the species listed are proportions of quadrats $\left(0.25 \mathrm{~m}^{2}\right)$ in which the species were seen. Meanwhile, benthic taxa mean percentage cover in the flank was twice as much as taxa mean percentage cover in the canyon head and south (Table 3). The rarefaction curve shows higher number of species on non-reef habitat (Figure 2B).

TABLE 3 | Number of taxa, mean percentage cover of colonial taxa, and mean density of discrete taxa.

\begin{tabular}{lccc}
\hline Habitat and site locations & \multicolumn{3}{c}{ Benthic taxa abundance } \\
\cline { 2 - 4 } & $\begin{array}{c}\text { Number of } \\
\text { taxa }\end{array}$ & Mean \% cover & $\begin{array}{c}\text { Mean density } \\
\left(\mathbf{m}^{-\mathbf{2}}\right)\end{array}$ \\
\hline Coral reef and rubble habitat & 41 & $0.30 \pm 0.25$ & $2.53 \pm 0.22$ \\
Non-reef habitat & 51 & $0.07 \pm 0.11$ & $3.58 \pm 0.25$ \\
Flank & 44 & $0.25 \pm 0.28$ & $2.18 \pm 0.28$ \\
Head & 39 & $0.10 \pm 0.16$ & $5.11 \pm 0.36$ \\
South & 29 & $0.14 \pm 0.15$ & $2.16 \pm 0.16$
\end{tabular}

\section{Benthic Taxa and Biodiversity}

Diversity was highest on the canyon flank and in non-reef habitats, although no significant $(P>0.05)$ differences were observed in benthic taxa diversity within the different habitats and site locations (Table 4). In relation to canyon site locations, taxa dominance (uneven distribution of species in a community) was highest in the flank and lowest in the canyon south while non-reef habitat exhibited high evenness (the relative abundance of species) and low dominance (Table 4). There was no significant $(P>0.05)$ difference observed in taxa evenness within the different habitats and site locations. Calculated $P$-values after applying Bonferroni correction among site locations and after performing a pairwise $z$-test among site locations for Shannon's diversity and taxa evenness were compared (and found not to be significant in both cases). Also sample points in the different site locations did not show spatial autocorrelation (Geary's $C_{\text {flank }}=1.1992, z=-10.510$; Geary's $C_{\text {head }}=1.1993, z=-11.039$; Geary's $C_{\text {south }}=1.1993, z=-11.431$ ) as well as in the different habitats (Geary's $C_{\text {coral reefandrubble }}=1.1994, z=-12.068$; Geary's $\left.C_{\text {non-reef }}=1.1996, z=-14.759\right)$.

\section{Benthic Faunal Composition}

Analysis of similarity estimate $(0.091<R<0.166 ; P<0.05)$ revealed that there were significant differences in the benthic taxa composition in the different habitats and site locations in the canyon. SIMPER revealed the taxa that most contributed to the observed structure in the benthic community within the PBC. The first seven taxa that most contributed to the observed compositional differences between habitats are L.glaberrima, $H$. dedritifera, C. cidaris, A. beatrix, A. fenestratum, Stichopathes cf. abyssicola and A. grandiflorus. Also, the first four species that contributed to the compositional differences between canyon head and flank are: L. glaberrima, H. dedritifera, C. cidaris, and Stichopathes cf. abyssicola; between canyon head and south 


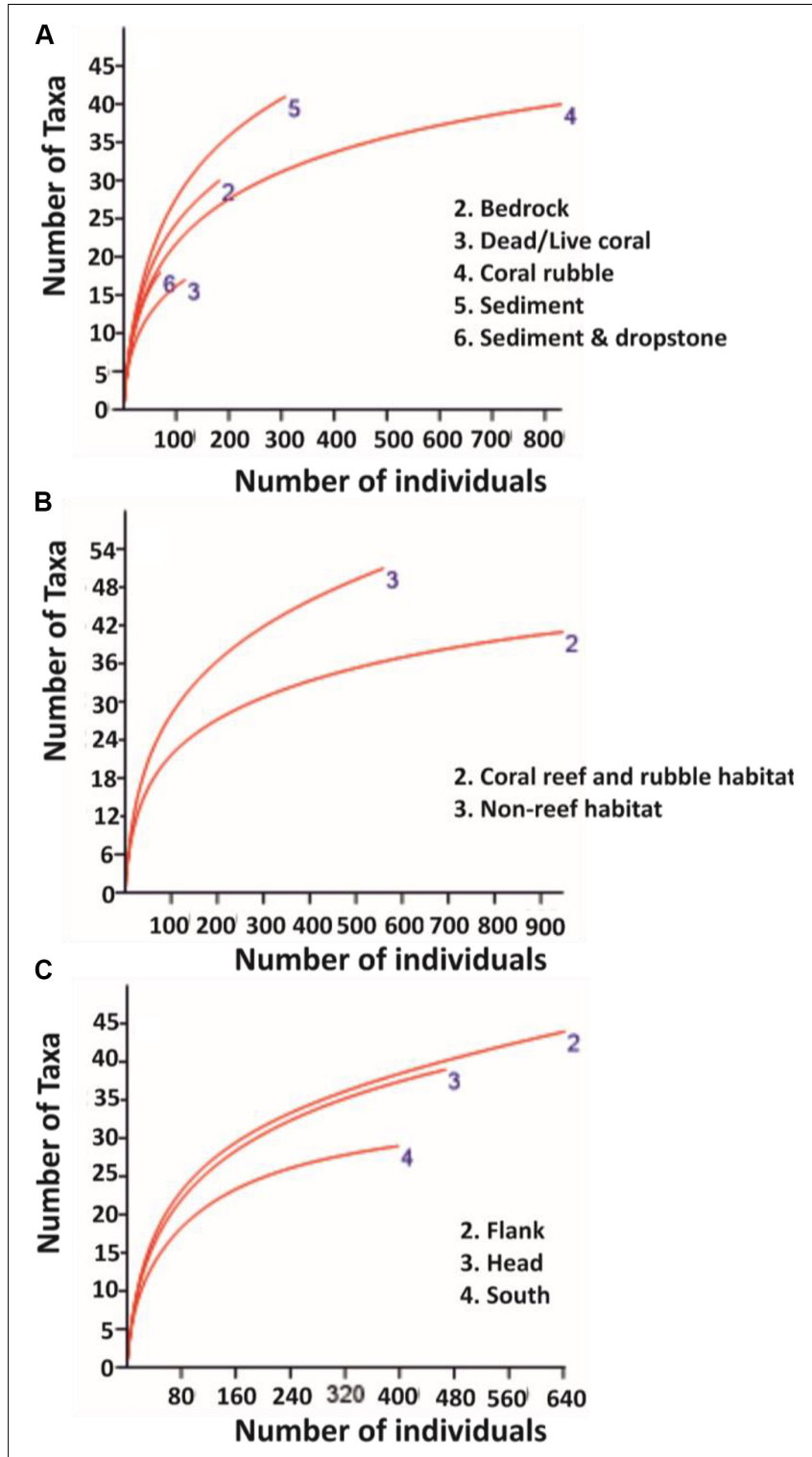

FIGURE 2 | Rarefaction curves for pooled data on: (A) substrata, (B) habitats, and (C) site locations. Sample size for substrata, the different habitats, and site locations are: bedrock $(n=141)$, dead/live coral $(n=65)$, coral rubble ( $n=666)$, sediment $(n=867)$, sediment and dropstone $(n=84)$, coral reef and rubble habitat $(n=731)$, non-reef habitat $(n=1092)$, canyon flank $(n=555)$, canyon head ( $n=612)$, and canyon south $(n=656)$, respectively.

are L. glaberrima, C. cidaris, A. beatrix, and $H$. dedritifera; and between flank and south are L. glaberrima, A. beatrix, $H$. dedritifera, and Stichopathes cf. abyssicola. Non-reef habitats are more variable than coral reef and rubble habitats (habitats are represented by the different shapes of the objects - triangles and circles) while the canyon head and south is more variable than the flank (site locations are represented by the different colors in the legend - red, blue, and green) as supported by nMDS ordination. Also, objects closer together are more similar (and tend to cluster) than are those farther apart. The nMDS analysis showed the dissimilarities among the benthic taxa grouped into habitats and site locations in the PBC (Figure 3).

\section{Relationship Between Seabed Terrain, Habitats, Site Locations and Benthic Fauna Distribution}

Aspect (northness and eastness) and rugosity were removed from the model because they were not significant $(P>0.05)$. The significance of the permutation test $(P=0.001)$ revealed the utility of the CCA model to evaluate the relationships among the terrain variables, habitats, site locations and the benthic fauna, although only $5.39 \%$ of the total variation was captured in the CCA. A similar permutation test also revealed that the terrain variables, habitats and site locations significantly $(P=0.001)$ accounted for the variation in benthic fauna distribution. The test also revealed the first two axes, CCA1 and CCA2, significantly $(P=0.001)$ accounted for the variation between the variables and taxa distribution, respectively (Figure 4). Axis CCA1 accounts for $46.95 \%$ of the variation while CCA2 accounts for $26.50 \%$ of the variation (Figure 4). Length of the arrow determines the degree of influence of the terrain variables, habitats and site locations on taxa distribution while a stronger relationship exist between taxa closer to the arrow than for those farther away (Figure 4). Furthermore, arrow lengths correlate to the ordination axes, where a longer arrow suggests a stronger correlation and potentially more variation being explained. Also, the perpendicularity between the arrows reveals the vital variables that contributed to benthic taxa distribution. Depth and slope were the most important terrain features, although depth exhibited greater influence on benthic taxa distribution (Figure 4). The categorical variables, habitat and site locations, were also important in the distribution of the benthic fauna in the PBC (Figure 4).

\section{Ecological Composition Motility}

Classification of the motile and sessile groups was made based on the biology of the organisms (Table 5). Sessile taxa were more abundant than the motile fauna in the two habitats and three site locations in the canyon (Table 5). Sessile fauna were high in abundance in each of the three site locations with the characteristic most common coral species Stichopathes cf. abyssicola and L. glaberrima and sponges A. beatrix and $H$. dedritifera. The most common motile fauna on coral reef and rubble and non-reef habitat was C. cidaris, while A. fenestratum constituted the most common motile species in non-reef habitat. Crinoid and Epizoanthus paguriphilus, respectively were the only motile echinoderm and cnidarian taxa observed in the canyon. Motile fauna were highest on the flank (Table 5).

\section{Mode of Feeding}

Classification of the suspension/filter feeders, predators and detritivorous was made based on the biology of the organisms (Table 5). Suspension/filter feeders constituted a greater 
percentage in the different habitats and site locations in the canyon (Table 5). Cnidarians identified in the canyons also demonstrate predation mode of feeding (Scharf et al., 2006; Bell, 2012; Massironi, 2016). The percentage composition of predators and non-predators for habitats were coral reef and rubble (40.68 and 59.32\%) and non-reef (57.63 and $42.37 \%$ ) whilst the percentage composition for the site locations were flank (50.85 and 49.15\%), head (38.98 and 61.02\%), and south (30.51 and 69.49\%), respectively. Some benthic organisms have adopted other modes of feeding such as grazing and scavenging (Macdonald et al., 2010; Massironi, 2016). For instance, the echinoderm C. cidaris and Porania sp. are grazers (Macdonald et al., 2010; Massironi, 2016). Suspension/filter feeders (e.g., the sponges $A$. beatrix and $H$. dedritifera) were observed where the sclerectinian L. pertusa and the black coral L. glaberrima appeared well developed and actively growing (i.e., making new polyps and accumulation of skeletal mass; e.g., Supplementary Figure S3C).

\section{Bathymetry, Oceanography, POM, and Hydrodynamics}

Ship-based multibeam bathymetry data (Figure 1 and Supplementary Figure S1) reveals the $\mathrm{PBC}$ as a double canyon with two branches separated by a ridge. Both branches exit into the Rockall Trough separately. The southern branch (Figure 1 and Supplementary Figure S1) is smaller with its head reaching to $1,900 \mathrm{~m}$ water depth near to station 65 and has an arm that cuts into the south eastern margin of the canyon up to a minimum water depth of $600 \mathrm{~m}$ and typically $700 \mathrm{~m}$. The main branch of the canyon has an asymmetrical profile with the southeastern margin represented by a tectonically

TABLE 4 | Estimates of Shannon's diversity and Pielou's evenness obtained from percentage and density abundance data in the different habitats and site locations in the Porcupine Bank Canyon (PBC).

\begin{tabular}{|c|c|c|c|c|}
\hline \multirow[t]{2}{*}{ Habitat and site locations } & \multicolumn{2}{|c|}{ Percentage estimate } & \multicolumn{2}{|c|}{ Density estimate } \\
\hline & Shannon's diversity $\left(\mathbf{H}^{\prime}\right)$ & Pielou's evenness $\left(\mathbf{J}^{\prime}\right)$ & Shannon's diversity $\left(\mathbf{H}^{\prime}\right)$ & Pielou's evenness $\left(\mathrm{J}^{\prime}\right)$ \\
\hline Coral reef and rubble habitat & 2.16 & 0.65 & 1.14 & 0.43 \\
\hline Non-reef habitat & 2.38 & 0.71 & 1.72 & 0.54 \\
\hline Flank & 2.36 & 0.74 & 1.97 & 0.65 \\
\hline Head & 2.23 & 0.67 & 1.44 & 0.56 \\
\hline South & 1.83 & 0.59 & 0.80 & 0.38 \\
\hline
\end{tabular}

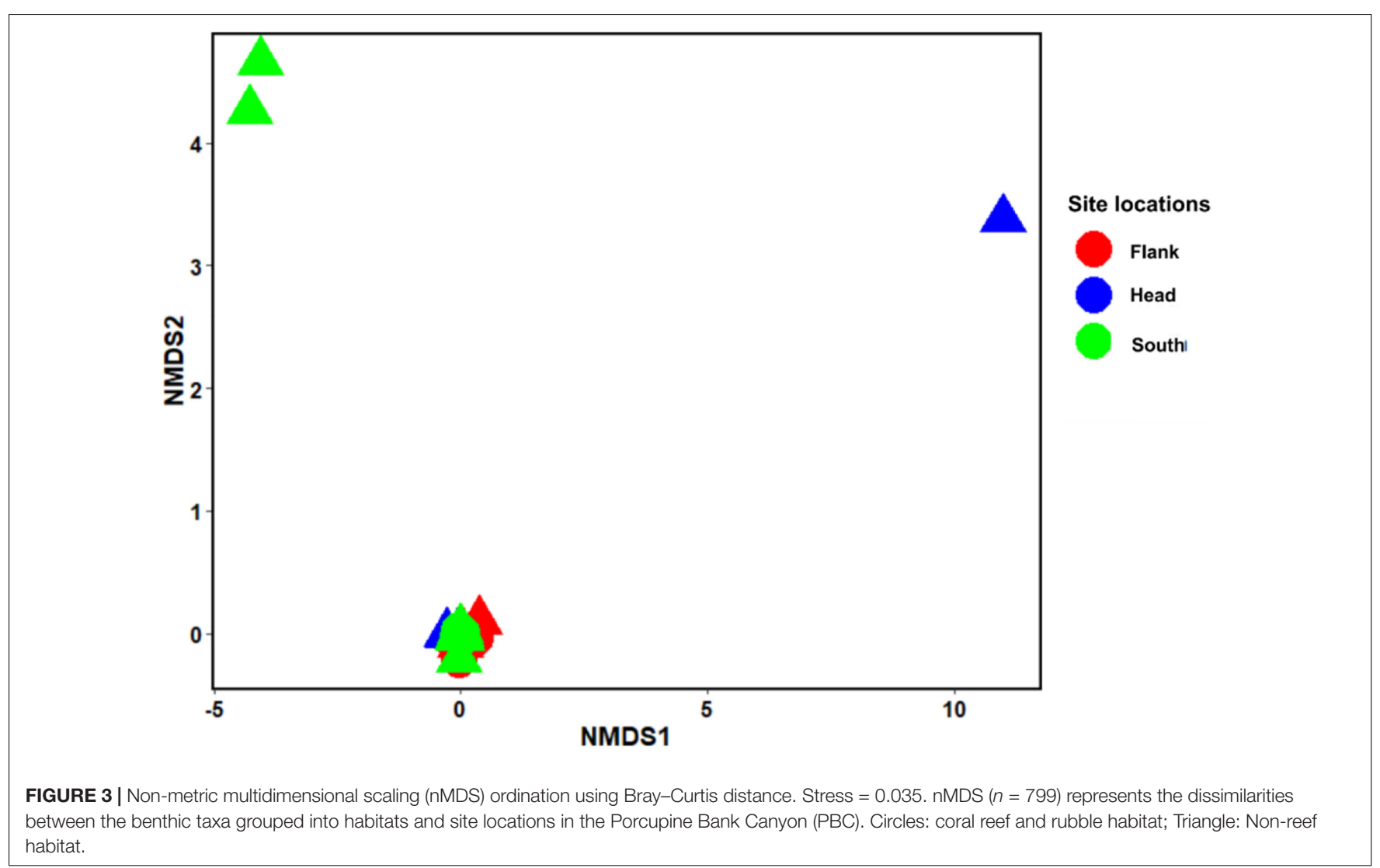




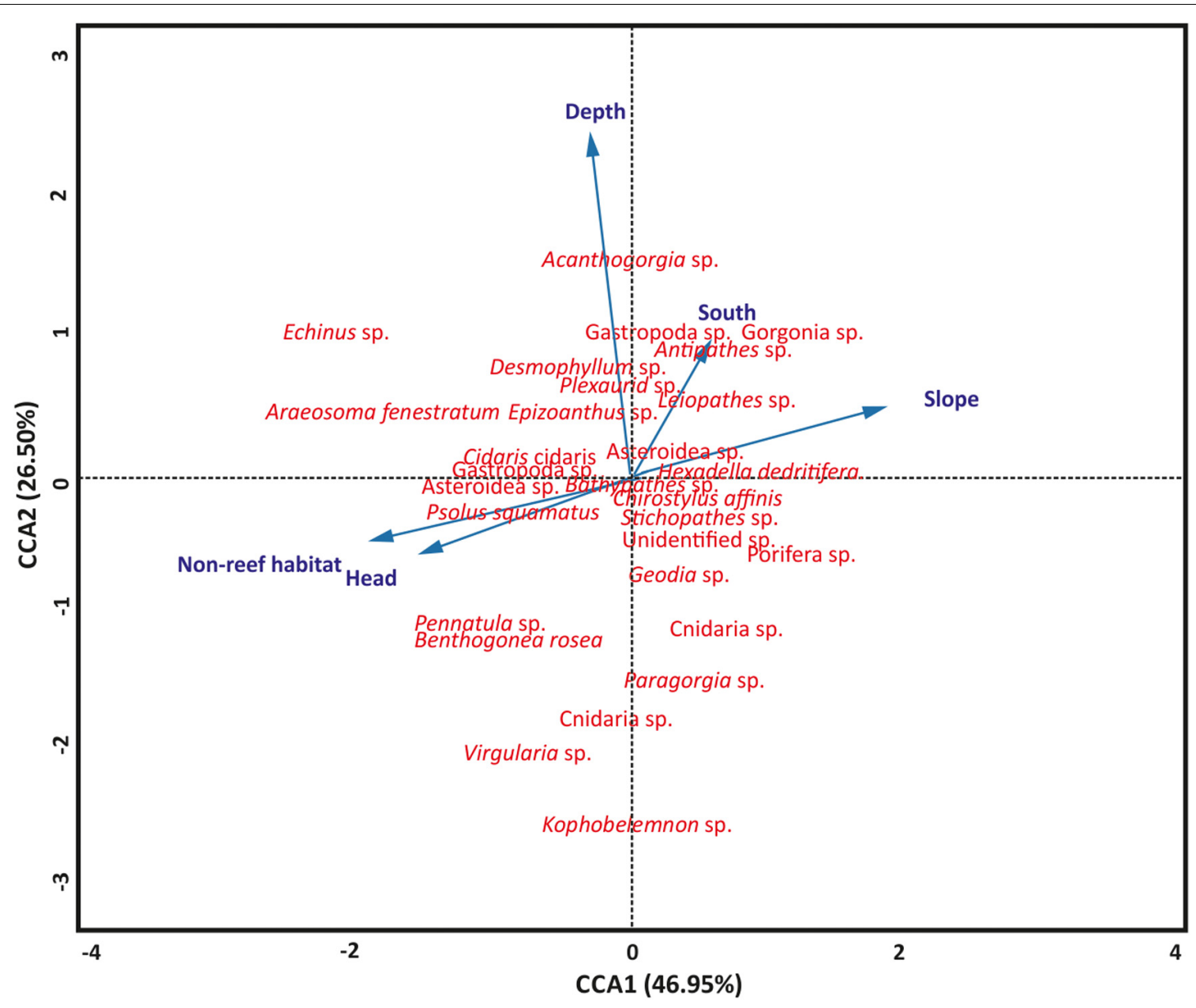

FIGURE 4 | Canonical-correlation analyses showing the relationship among terrain features (slope and depth), habitat, site locations, and benthic taxa distribution $(n=799)$. CCA, canonical correspondence analysis. Blue arrows are terrain variables, habitats and site location represented as vectors.

TABLE 5 | Percent composition of the functional groups in the different habitats and site locations in the Porcupine Bank Canyon (PBC).

Habitat and site locations

\begin{tabular}{llc}
\cline { 3 - 3 } & \multicolumn{2}{c}{ Motility } \\
\cline { 3 - 3 } & Motile & Sessile \\
\hline Coral reef and rubble habitat & 26.00 & 74.00 \\
Non-reef habitat & 35.00 & 65.00 \\
Flank & 38.00 & 62.00 \\
Head & 27.50 & 72.50 \\
South & 27.00 & 73.00
\end{tabular}

Percentage (\%) composition

Mode of feeding

Suspension/filter feeder

Detritivore

76.00

67.00

62.00

75.00

77.00
24.00

33.00

38.00

25.00

23.00 faulted, steep cliff from 1,600 to $750 \mathrm{~m}$ water depth. On the north eastern margin, the head of the canyon is more gently sloping, with even gentler gradients defining the north western margin (Supplementary Figure S1). Small gullies around the canyon margins feed into the two branches. The rim of the canyon is plateaued.

Conductivity-temperature-depth data reveals that the eastern North Atlantic water (ENAW) was the main watermass generally bathing the benthic community from $600-1,200 \mathrm{~m}$ in the PBC while the labrador sea water (LSW) occurred below 1,200 $\mathrm{m}$ (Supplementary Figure S5). The temperature and salinity limits between $600-1,000 \mathrm{~m}$ are $6.5-9.8^{\circ} \mathrm{C}$ and $35.18-$ 35.5 psu, respectively.

Particulate organic matter concentration ranged between 10-3,965 $\mu \mathrm{g}^{-1}$. POM was highest in the south whereas concentrations in the northern canyon head and flank were 
similar to each other (Supplementary Figure S6). Mean current speed recorded in the canyon ranged between $18.2-31.3 \mathrm{~cm}$ $\mathrm{s}^{-1}$. The highest mean current speed was measured on the flank $\left(31.3 \mathrm{~cm} \mathrm{~s}^{-1}\right)$ from the southerly direction, followed by measurement in the south $\left(25.4 \mathrm{~cm} \mathrm{~s}^{-1}\right)$ from the northwesterly direction while current speed of $18.2 \mathrm{~cm} \mathrm{~s}^{-1}$ at the head was recorded from the northerly direction.

\section{DISCUSSION}

\section{Patterns of Fauna Composition and Diversity}

This research presents the findings of an extensive ROV-based survey of the PBC, which includes a detailed analysis of $46.81 \mathrm{~km}$ of ROV HD video data detailing the different substrata and habitats within the PBC including a large coverage of coral reef and rubble and non-reef habitats (Table 1). Although the quadrat size $\left(0.25 \mathrm{~m}^{2}\right)$ was small, it was necessary to sample a standardized area as both oblique and vertical images were used, and also due to the fact that the number of species is proportional to the area being sampled (Rosenzweig, 1995). According to Clark et al. (2010), substratum characteristics influence benthic taxa composition. Generally, coral rubble and dead/live corals have been reported to support large numbers of species and high Shannon's diversity compared to non-reef habitat (Jonsson et al., 2004; Mortensen and Fosså, 2006; Henry and Roberts, 2007; Wienberg et al., 2008) with a few studies reporting lower taxa richness and diversity on coral rubble habitat (Robert et al., 2014; Buhl-Mortensen L. et al., 2017). Moreover, as the sample size for the substrata varied, it was appropriate to pool them into habitats to mitigate the effect of uneven sample size on taxa number (Figure 2). As such, the different substrata in the present study were resolved into potentially more diverse habitats (coral reef and rubble) and less diverse habitats (nonreef) to allow for the evaluation of differences in taxa diversity and richness between the two habitats and the different site locations in the PBC.

Most surveys of cold-water corals are exploratory in nature, and tend to focus their survey lines on reefs and/or interesting features which most likely limit their biodiversity assessments (Buhl-Mortensen P. et al., 2017). According to Buhl-Mortensen P. et al. (2017), survey areas which were most likely to support corals were chosen for their study. However, in the present study, a canyon-wide systematic survey pattern was applied covering all habitats proportional to seabed area. High biodiversity was noted on coral reef and rubble but they are localized hotspots. On balance, there is a higher number of taxa identified in non-reef habitat than coral reef and rubble (Figure 2 and Table 3), and consequently this influences the Shannon's diversity observed in non-reef compared to coral reef and rubble habitat, although this observed difference was not significant (Table 4). A more proportional abundance of benthic fauna in the non-reef habitat and the canyon flank resulted in the highest Shannon's diversity and taxa evenness estimated in the canyon flank, but again there was no significant difference observed. Similarly, Ramirez-Llodra et al. (2010) observed high Pielou's evenness and Shannon's diversity in the canyon head and walls of the Blanes submarine canyon in the Mediterranean. In line with the present study, the sponges $A$. beatrix and $H$. dedritifera have been previously noted to colonize coral reef and rubble habitats in high abundance (Pfannkuche et al., 2004; BuhlMortensen L. et al., 2017; Boolukos et al., 2019). The ubiquitous and frequent presence of the glass sponges $A$. beatrix and $H$. dedritifera were observed on all substrates in relatively high abundance during each dive. Similarly, the black corals L. glaberrima and Stichopathes cf. abyssicola occurred on all substrates in comparatively high abundance during each dive. Faunal dominance was low in the non-reef habitat and canyon flank, but this observation was also not significant (Table 4). Non-dependence (from Geary's $C$ test) of sample points in the different habitats and site locations was sufficient reason to use either a $t$ - or $z$-test (both tests assume independence of samples, although a $z$-test was used in the present study) to assess the level of significance of taxa diversity and evenness among habitats and site locations in the PBC.

There are more exposed hard seabed substrates on the canyon flank (Table 1) and the steepness $\left(20-60^{\circ}\right)$ of the canyon flank prevents sediment accumulation on this substrate. In addition, this exposed bedrock on the flank and non-reef habitat provides extra substrate for sessile benthic faunal attachment. According to Wienberg et al. (2008) and Vertino et al. (2010), substrate variability typically gives rise to high biodiversity. In general, hard substrata and dropstones provide suitable habitats for Stylasterids (Cairns, 1992). Similarly, our results show a low abundance of the Stylasterid Pliobothrus symmetricus in coral reef and rubble habitat with higher abundances in non-reef habitat. There is a gradation from a more coral-rich area in the south to a more sandy sediment area in the north of the PBC. As a result, high abundance of echinoderms on sediments and sediment and dropstone were observed in the north. Particularly, C. cidaris and A. fenestratum, and $P$. squamatus are the taxa that influence the abundance of echinoderms on sediments and sediment and dropstone habitats, respectively, in the canyon head in the north. In addition, the sea pens Kophoblemnon sp. and Pennatula sp. are abundant in the deeper parts of the PBC which is mostly sediment (Hogan et al., 2019).

\section{Benthic Fauna Composition and POM}

High L. pertusa abundance in the canyon south (Supplementary Figure S7) may be due to the high concentrations of POM in the south of the canyon (Supplementary Figure S6). Kiriakoulakis et al. (2007) shows that POM are food source for benthic communities. Also, food availability and composition in a submarine canyon structure the spatial distribution of benthic fauna (Huvenne et al., 2011; Leduc et al., 2014). POM in the sediment becomes available to suspension feeders through resuspension by hydrographic or biological activities in the canyon. However, human activities such as trawl fishing and objects (Supplementary Figure S8G) dropped to the seafloor also resuspend POM and make them available to the benthic community (Wilson et al., 2015: Daly et al., 2018). In the PBC, evidence of 
past fishing activities included fish traps, fishing lines (Supplementary Figure S8), and possible trawl/tool marks (Supplementary Figure S8).

\section{Ecological Composition}

The biology of the benthic taxa influences the ecological composition of benthic organisms in the PBC (Danovaro et al., 2008). The burrowing activities of some benthic taxa can resuspend sediment and POM, affecting structure of the benthic community (Lampitt et al., 1986; Smith et al., 1986). In addition, the variability of taxa composition can be attributed to oceanographic and environmental factors prevailing in the canyon (Henry et al., 2014). High abundances of motile fauna were observed in non-reef habitat and on the flank. The abundance of sessile fauna corresponds with the abundance of suspension/filter feeders in the canyon. Similar observation was made in other deep-sea studies (Jonsson et al., 2004; Henry and Roberts, 2007). In line with Massironi (2016), cnidarians are classified as predators (ambush or passive) in the present study. Massironi (2016) classified cnidarians as predators probably because they get their food by waiting in ambush (and this seems to be the case). The ambush (sit and wait) mode of predation is generally demonstrated by organisms that have low energy requirements and also when the prey (e.g., zooplankton, calanoid copepods, amphipods, euphausiid crustaceans) are dense (Scharf et al., 2006; Bell, 2012). Moreover, the organism's ability to capture live prey by actively focusing the prey through its mouth with the aid of its tentacles constitute and fit the definition for predation. The high abundance of suspension/filter feeders and predators in the PBC could be explained by the high concentrations of resuspended POM (1,330-3,965 $\left.\mu \mathrm{g} \mathrm{l}^{-1}\right)$ and the low rate of sedimentation in the high energy environment (Jonsson et al., 2004; Henry and Roberts, 2007). According to Gardner (1989) resuspended particle concentrations may exceed $5,000 \mu \mathrm{g}^{-1}$ in high energy environments of submarine canyons.

\section{Environmental Drivers of Benthic Fauna Distribution}

\section{Relationship Between Seabed Terrain, Habitats, Site Locations and Benthic Fauna Distribution}

Canonical correspondence analysis was performed to evaluate the relationship between the terrain features (depth, rugosity, aspect, and slope), habitats, site locations and the benthic megafauna in the PBC. In the present study, seabed terrain features (depth and slope) were the most important terrain features that affected the spatial distribution of benthic fauna while non-reef habitat and canyon head are the categorical variables that affected fauna distribution (Figure 4). The contributions of non-reef habitat and site locations on benthic taxa distribution are succinctly observed from the high taxa richness and Shannon's diversity that they support in the PBC. The canyon morphology, revealed by the MBES data (Figure 1 and Supplementary Figure S1), contributes to the distribution patterns in the canyon as the CCA analysis showed that the different site locations (which show different morphologies) also influenced taxa distribution. Henry and Roberts (2007) recognized that vertical habitat heterogeneity significantly influences benthic fauna diversity. In addition, depth and other geomorphic canyon features have been found to affect the spatial distribution of benthic fauna (De Mol et al., 2011; Kenchington et al., 2014; Fanelli et al., 2018; Trotter et al., 2019).

\section{Oceanography and Hydrodynamics}

The low variation in benthic fauna distribution accounted for by the CCA1 and CCA2 axes, respectively (Figure 4) suggest that in addition to seabed terrain, substrata and the different site locations and morphologic features, other factors such as oceanography and hydrodynamics may contribute to the pattern of benthic fauna distribution observed in the PBC. Cold-water coral distribution is largely influenced by temperature and salinity (Freiwald, 2002; Roberts et al., 2006; Davies et al., 2008; Dullo et al., 2008; Naumann et al., 2014). In the present study, actively growing and well developed corals (e.g., Supplementary Figures S3C, S8D) are restricted to a bathymetric depth of 600-1,000 $\mathrm{m}$ and permanently immersed in ENAW (Supplementary Figure S5), suggesting that ENAW influences the distribution of the benthic fauna in the PBC. A similar trend of fauna distribution was observed by Mienis et al. (2007) in the Rockall Trough margins. However, poorly developed corals were observed to coincide with LSW below 1,200 m (Supplementary Figure S5). It is noted that high taxa number and Shannon's diversity were observed on the canyon flank where mean current speed was highest $\left(31.3 \mathrm{~cm} \mathrm{~s}^{-1}\right)$, although no direct link between current speed and benthic fauna distribution was assessed. It is thus highly probable that current regimes influence benthic fauna distribution in the PBC. Deep-sea currents and POM have also been recognized to influence the distribution of benthic fauna (Levin et al., 2001; Cunha et al., 2011; Henry et al., 2014).

\section{Conservation and Management of the Benthic Fauna and Habitats in the PBC}

The expansion of human activities into the deep-seas, coupled with climate change most likely threaten the coral ecosystem in deep-seas (including the PBC) as human activities impact negatively on species distribution and diversity (Hall-Spencer et al., 2002; Glover and Smith, 2003; Grehan et al., 2004; Gass and Roberts, 2006; Kaiser and Barnes, 2008; Danovaro et al., 2017; Volkov et al., 2017; Durack et al., 2018; Miller et al., 2020). Management and conservation biologists strive to prevent habitats and species from permanent damage and declines. Also, scientists have observed that some proportions of habitat loss and population decline are recoverable while some losses and declines are permanent, although many of these losses and declines could have been prevented (Young, 2000). Therefore, management is required to recover and fix those that can be fixed whilst ensuring that permanent losses and declines do not occur going forward. To this effect, we believe that the findings of the present study would help conservation and management efforts in regulating the activities of key 
stakeholders who interact with the $\mathrm{PBC}$ in order to protect the different habitats and benthic fauna therein. Canyon-wide conservation and management of the $\mathrm{PBC}$ is advocated here due to the high benthic fauna abundance and consequently high diversity observed in non-reef habitat (although not significant) contrasting to what is usually reported in literature. Scientists have recognized that processes/activities (e.g., increased sedimentation through trawl fishing) happening in one part of the canyon can potentially impact life elsewhere in the canyon (Huvenne and Davies, 2014; Martín et al., 2014) and hence the need to consider canyon-wide conservation and management of the PBC.

\section{CONCLUSION}

The PBC is a submarine canyon on the Irish margin disconnected from across-shelf transport and containing cold-water coral habitats. As such, it provides a perfect ecosystem to identify environmental control on cold-water coral and canyon habitats without terrigenous inputs. The present study suggests that the spatial distribution of benthic fauna is associated with the availability of POM, oceanographic and hydrographic processes, seabed terrain (depth and slope), canyon morphologic features at the different site locations and habitats of the PBC. Analysis of the benthic taxa of the PBC has revealed significant structure in the faunal and ecological composition. Habitat heterogeneity evidenced by the different substrata and morphologic features in the canyon contributes to the trend of diversity, evenness and taxa distribution observed in the canyon. The present study also suggests that non-reef habitats have the potential to hold high benthic fauna diversity in submarine canyons. However, there is the need for standardization of methods for deep-sea community studies, to allow for comparability and effective conservation and management processes in submarine canyons, which in many cases, are limited by the cost of deepsea research.

\section{DATA AVAILABILITY STATEMENT}

The raw data supporting the conclusions of this article will be made available by the authors, without undue reservation.

\section{AUTHOR CONTRIBUTIONS}

JA: design, write up, data analysis, and data collection. AL: data collection, data analysis, and draft editing. $\mathrm{KH}$ : data collection and data analysis. RO'R: technical advice and draft editing. LO'R: data collection. AW: data collection, technical advice and draft editing. All authors contributed to the success of the manuscript.

\section{FUNDING}

The authors thank the crew and officers of RV Celtic Explorer and ROV Holland 1 for their support and advice during data acquisition in the Porcupine Bank Canyon. Ship time on the RV Celtic Explorer was funded by the Marine Institute under the 2017 and 2018 Ship Time Program of the National Development. They thank the funders of MMMonKey_Pro project (grant number: 16/IA/4528) Science Foundation Ireland (SFI), Geological Survey Ireland, and the Marine Institute. $\mathrm{AL}$ is supported by the European Union's Horizon 2020 Research and Innovation Program "iAtlantic" project (grant number: 818123).

\section{SUPPLEMENTARY MATERIAL}

The Supplementary Material for this article can be found online at: https://www.frontiersin.org/articles/10.3389/fmars.2020. 571820/full\#supplementary-material

Supplementary Figure S1 | A map showing the area of the Porcupine Bank Canyon (PBC) and the Southwest Porcupine Bank designated as special area of conservation (SAC; demarcated by red polygon). Coordinates of area of PBC designated as SAC are listed in Supplementary Table S5 (as a separate excel file).

Supplementary Figure S2 | Benthic taxa in the Porcupine Bank Canyon (PBC). Scale bar = $10 \mathrm{~cm}$ : (A) Opisthoteuthis agassizii (B) Porifera sp. (C) Crinoid (D) Kophobelemnon sp. (E) Geodia sp. (F) Leiopathes glaberrima (G) Chrysogorgia sp. (H) Pennatula sp. (I) Bathypathes sp. (J) Hexadella dedritifera (K) Anthomastus grandiflorus (L) Araeosoma fenestratum.

Supplementary Figure S3 | Benthic taxa in the Porcupine Bank Canyon (PBC). Scale bar = $10 \mathrm{~cm}$ : (A) Pliobothrus symmetricus (B) Asteroidea sp. (C) Lophelia pertusa.

Supplementary Figure S4 | Benthic taxa in the Porcupine Bank Canyon (PBC). Scale bar = $10 \mathrm{~cm}$ : (A) Unidentified sp. (B) Euplectellid sp. (C) Asteroidea sp. (D) Actinaria sp. (E) Chaecon affinis (F) Aphrocallistes beatrix (G) Ascidian sp. (H) Asteroidea sp. (I) Bathypathes sp. with squat crab (J) Porania sp. (K) Decapoda sp. (L) Stichopathes cf. abyssicola (M) Paramuricea sp.

Supplementary Figure S5 | T-S plot of conductivity-temperature-depth (CTD) data with density contours to characterize the water mass properties through a $1,200 \mathrm{~m}$ depth from the surface water in the Porcupine Bank Canyon (PBC): eastern North Atlantic water (ENAW), mediterranean outflow water (MOW), and labrador sea water (LSW). Space between broken lines reveals the predicted density envelope for NE Atlantic CWCs (Dullo et al., 2008).

Supplementary Figure S6 | Particulate organic matter (POM) distribution in the Porcupine Bank Canyon (PBC).

Supplementary Figure S7 | Lophelia pertusa mean percentage cover among site locations in the Porcupine Bank Canyon (PBC). A significant $(P<0.05)$ difference between the canyon south and flank was observed. The sample size for canyon flank, head, and south are 555, 612, and 656, respectively.

Supplementary Figure S8 | Seabed types that exist in the Porcupine Bank Canyon (PBC) and identified evidence of human activities, scale bar $=10 \mathrm{~cm}$ : (A) sediment and dropstone (SD; $n=84)$, (B) sediment (S; $n=867$ ), (C) bedrock (B; $n=141$ ), (D) live/dead coral (DL; $n=65)$, (E) coral rubble (R; $n=666)$, (F) fishing line, (G) metal fish trap, (H) tool marks (837 m), (I) tool marks (774 m).

Supplementary Table S1 | ROV transects in the Porcupine Bank Canyon (PBC), length $(\mathrm{km})$, mean depth, depth range, and date for each transect.

Supplementary Table S2 | Seabed classification system used for this study.

Supplementary Table S4 | Seawater samples from the Porcupine Bank Canyon (PBC) collected on 08-08-2018 showing Time (UTC), station number, sample depth and coordinates. 


\section{REFERENCES}

Addamo, A. M., Vertino, A., Stolarski, J., García-Jiménez, R., Taviani, M., and Machordom, A. (2016). Merging scleractinian genera: the overwhelming genetic similarity between solitary Desmophyllum and colonial Lophelia. BMC Evol. Biol. 16:108. doi: 10.1186/s12862-016-0654-8

Akhmetzanov, A. M., Kenyon, N. H., Ivanov, M. K., Wheeler, A. J., and Shashkin, P. V. (2003). "Giant carbonate mounds and current-swept seafloors on the slopes of the Southern Rockall Trough Margins," in European Margin Sediment Dynamics, eds J. Mienert and P. Weaver (Berlin: Springer).

Allen, S. E., Vindeirinho, C., Thomson, R. E., Foreman, M. G., and Mackas, D. L. (2001). Physical and biological processes over a submarine canyon during an upwelling event. Can. J. Fish. Aquat. Sci. 58, 671-684. doi: 10.1139/f01-008

Aymà, A., Aguzzi, J., Canals, M., Lastras, G., Mecho, A., and Iacono, C. L. (2019). 26 Occurrence of Living Cold-Water Corals at Large Depths Within Submarine Canyons of the Northwestern Mediterranean Sea. In Mediterranean Cold-Water Corals: Past, Present and Future. Cham: Springer, 271-284.

Belgrano, A., and Reiss, J. (2011). The Role of Body Size in Multispecies Systems, Vol. 45. Cambridge, MA: Academic Press.

Bell, W. J. (2012). Searching Behaviour: The Behavioural Ecology of Finding Resources. Berlin: Springer.

Bivand, R. S., Pebesma, E. J., Gómez-Rubio, V., and Pebesma, E. J. (2008). Applied Spatial Data Analysis with R, Vol. 747248717. New York, NY: Springer, 237-268.

Boolukos, C. M., Lim, A., O'Riordan, R. M., and Wheeler, A. J. (2019). Coldwater corals in decline-a temporal (4 year) species abundance and biodiversity appraisal of complete photomosaiced cold-water coral reef on the Irish Margin. Deep Sea Res. Part I Oceanogr. Res. Pap. 146, 44-54. doi: 10.1016/j.dsr.2019. 03.004

Bosley, K. L., Lavelle, J. W., Brodeur, R. D., Wakefield, W. W., Emmett, R. L., Baker, E. T., et al. (2004). Biological and physical processes in and around Astoria submarine Canyon, Oregon, USA. J. Mar. Syst. 50, 21-37. doi: 10.1016/ j.jmarsys.2003.06.006

Buhl-Mortensen, L., Serigstad, B., Buhl-Mortensen, P., Olsen, M. N., Ostrowski, M., Błaźewicz-Paszkowycz, M., et al. (2017). First observations of the structure and megafaunal community of a large Lophelia reef on the Ghanaian shelf (the Gulf of Guinea). Deep Sea Res. Part II Top. Stud. Oceanogr. 137, 148-156. doi: 10.1016/j.dsr2.2016.06.007

Buhl-Mortensen, P., Gordon, D. C. Jr., Buhl-Mortensen, L., and Kulka, D. W. (2017). First description of a Lophelia pertusa reef complex in Atlantic Canada. Deep Sea Res. Part I Oceanogr. Res. Pap. 126, 21-30. doi: 10.1016/j.dsr. 2017.05.009

Cairns, S. D. (1992). Worldwide distribution of the Stylasteridae (Cnidaria: Hydrozoa). Scientia Mar. 56, 125-130.

Canals, M., Puig, P., Durrieu de Madron, X., Heussner, S., Palanques, A., and Fabres, J. (2006). Flushing submarine canyons. Nature 444, 354-357. doi: 10.1038 /nature05271

Clark, M. R., Rowden, A. A., Schlacher, T., Williams, A., Consalvey, M., Stocks, K. I., et al. (2010). The ecology of seamounts: structure, function, and human impacts. Annu. Rev. Mar. Sci. 2, 253-278. doi: 10.1146/annurev-marine120308-081109

Clarke, K. R., and Gorley, R. N. (2001). PRIMER (Plymouth Routines in Multivariate Ecological Research) v5: User Manual/Tutorial. Plymouth: PrimerE Ltd, 1-91.

Clarke, K. R., and Warwick, R. M. (2001). Change in Marine Communities: An Approach to Statistical Analysis and Interpretation, 2nd Edn. Plymouth: PRIMER-E, Ltd., Plymouth Marine Laboratory.

Cunha, M. R., Paterson, G. L., Amaro, T., Blackbird, S., de Stigter, H. C., Ferreira, C., et al. (2011). Biodiversity of macrofaunal assemblages from three Portuguese submarine canyons (NE Atlantic). Deep Sea Res. Part II Top. Stud. Oceanogr. 58, 2433-2447. doi: 10.1016/j.dsr2.2011.04.007

Daly, E., Johnson, M. P., Wilson, A. M., Gerritsen, H. D., Kiriakoulakis, K., Allcock, A. L., et al. (2018). Bottom trawling at Whittard Canyon: evidence for seabed modification, trawl plumes and food source heterogeneity. Prog. Oceanogr. 169, 227-240. doi: 10.1016/j.pocean.2017.12.010

Danovaro, R., Corinaldesi, C., Dell'Anno, A., and Rastelli, E. (2017). Potential impact of global climate change on benthic deep-sea microbes. FEMS Microbiol. Lett. 364:fnx214.
Danovaro, R., Gambi, C., Dell'Anno, A., Corinaldesi, C., Fraschetti, S., Vanreusel, A., et al. (2008). Exponential decline of deep-sea ecosystem functioning linked to benthic biodiversity loss. Curr. Biol. 18, 1-8. doi: 10.1016/j.cub.2007.11.056

Davies, A. J., Wisshak, M., Orr, J. C., and Roberts, J. M. (2008). Predicting suitable habitat for the coldwater coral Lophelia pertusa (Scleractinia). Deep Sea Res. Part I Oceanogr. Res. Pap. 55, 1048-1062. doi: 10.1016/j.dsr.2008.04.010

Davies, J. S., Howell, K. L., Stewart, H. A., Guinan, J. C., and Golding, N. (2014). This issue, Defining biological assemblages (biotopes) of conservation interest in the submarine canyons of the South West Approaches (offshore United Kingdom) for use in marine habitat mapping. Deep Sea Res. II 104, 208-229. doi: 10.1016/j.dsr2.2014.02.001

de Jesus Mendes, P. A., Thomsen, L., Garcia, R., and Gust, G. (2011). Transport of persistent organic pollutants by organo-mineral aggregates (OMAs) in the Lisboa-Setubal Canyon system. Deep Sea Res. Part II Top. Stud. Oceanogr. 58, 2345-2353. doi: 10.1016/j.dsr2.2011.08.010

De Leo, F. C., Smith, C. R., Rowden, A. A., Bowden, D. A., and Clark, M. R. (2010). Submarine canyons: hotspots of benthic biomass and productivity in the deep sea. Proc. R. Soc. B Biol. Sci. 277, 2783-2792. doi: 10.1098/rspb.2010.0462

De Mol, L., Van Rooij, D., Pirlet, H., Greinert, J., Frank, N., Quemmerais, F., et al. (2011). Coldwater coral habitats in the Penmarc'h and Guilvinec Canyons (Bay of Biscay): deep-water versus shallow-water settings. Mar. Geol. 282, 40-52. doi: 10.1016/j.margeo.2010.04.011

de Stigter, H. C., Boer, W., de Jesus Mendes, P. A., Jesus, C. C., Thomsen, L., van den Bergh, G. D., et al. (2007). Recent sediment transport and deposition in the Nazaré Canyon, Portuguese continental margin. Mar. Geol. 246, 144-164. doi: 10.1016/j.margeo.2007.04.011

Derrick, B., Dobson-Mckittrick, A., Toher, D., and White, P. (2015). Test statistics for comparing two proportions with partially overlapping samples. J. Appl. Quant. Methods 10, 1-14.

Dorschel, B., Wheeler, A. J., Huvenne, H. A. I., and de Haas, H. (2009). Cold-water coral mounds in an erosive environmental setting: TOBI side-scan sonar data and ROV video footage from the northwest Porcupine Bank, NE Atlantic. Mar. Geol. 264, 218-229. doi: 10.1016/j.margeo.2009.06.005

Dorschel, B., Wheeler, A. J., Monteys, X., and Verbruggen, K. (2010). Atlas of the Deep-water Seabed: Ireland. Dordrecht: Springer, 164.

Doyle, C., Murphy, L., O'Leary, P., and O’Neill, M. (2005). Quantitative analysis of three ecosystems for Leaving Certificate Biology. Wexford: Co. Wexford Education Centre.

Dubé, J., and Legros, D. (2014). Spatial Econometrics Using Microdata. London: John Wiley \& Sons.

Dullo, W. C., Flögel, S., and Rüggeberg, A. (2008). Cold-water coral growth in relation to the hydrography of the Celtic and Nordic European continental margin. Mar. Ecol. Prog. Ser. 371, 165-176. doi: 10.3354/meps07623

Durack, P. J., Gleckler, P. J., Purkey, S. G., Johnson, G. C., Lyman, J. M., and Boyer, T. P. (2018). Ocean warming: from the surface to the deep in observations and models. Oceanography 31, 41-51. doi: 10.5670/oceanog.2018.227

Fabri, M. C., Pedel, L., Beuck, L., Galgani, F., Hebbeln, D., and Freiwald, A. (2014). Megafauna of vulnerable marine ecosystems in French Mediterranean submarine canyons: spatial distribution and anthropogenic impacts. Deep Sea Res. Part II Top. Stud. Oceanogr. 104, 184-207. doi: 10.1016/j.dsr2.2013.06.016

Fanelli, E., Bianchelli, S., and Danovaro, R. (2018). Deep-sea mobile megafauna of Mediterranean submarine canyons and open slopes: analysis of spatial and bathymetric gradients. Prog. Oceanogr. 168, 23-34. doi: 10.1016/j.pocean.2018. 09.010

Freiwald, A. (2002). "Reef-forming cold-water corals," in Ocean margin systems, eds G. Wefer, D. Billett, D. Hebbeln, B. B. Jørgensen, M. Schlüter, and T. C. E. van Weering (Heidelberg: Springer), 365-385. doi: 10.1007/978-3-662-051 27-6_23

Fussey, G. D. (1995). Biodiversity and species discovery curves: a teaching simulation. J. Biol. Educ. 29, 41-45. doi: 10.1080/00219266.1995.96 55417

Gardner, W. D. (1989). Baltimore Canyon as a modern conduit of sediment to the deep sea. Deep Sea Res. Part A Oceanogr. Res. Pap. 36, 323-358. doi: 10.1016/0198-0149(89)90041-1

Gass, S. E., and Roberts, J. M. (2006). The occurrence of the cold-water coral Lophelia pertusa (Scleractinia) on oil and gas platforms in the North Sea: colony growth, recruitment and environmental controls on distribution. Mar. Pollut. Bull. 52, 549-559. doi: 10.1016/j.marpolbul.2005.10.002 
Glover, A. G., and Smith, C. R. (2003). The deep-sea floor ecosystem: current status and prospects of anthropogenic change by the year 2025. Environ. Conserv. 30, 219-241. doi: 10.1017/s0376892903000225

Greene, H. G., Clarke, S. H. Jr., and Kennedy, M. P. (1991). “Tectonic evolution of submarine canyons along the California continental margin," in From Shoreline to Abyss: Contributions in Mar. Geol. in Honor of Francis Parker Shepard, ed. R. H. Osborne (Tulsa, OK: SEPM Special Publication), 231-248.

Grehan, A., Unnithan, V., Wheeler, A., Monteys, X., Beck, T., Wilson, M., et al. (2004). "Evidence of major fisheries impact on cold-water corals in the deepwaters off the Porcupine Bank, west coast of Ireland: Are interim management measures required," in Proceedings of the ICES Annual Science Symposium, Vigo.

Guinan, J., Grehan, A. J., Dolan, M. F., and Brown, C. (2009). Quantifying relationships between video observations of cold-water coral cover and seafloor features in Rockall Trough, west of Ireland. Mar. Ecol. Prog. Ser. 375, 125-138. doi: 10.3354/meps07739

Hall-Spencer, J., Allain, V., and Fosså, J. H. (2002). Trawling damage to Northeast Atlantic ancient coral reefs. Proc. R. Soc. Lond. Ser. B Biol. Sci. 269, 507-511. doi: $10.1098 / \mathrm{rspb} .2001 .1910$

Hammer, Ø., Harper, D. A., and Ryan, P. D. (2001). PAST: paleontological statistics software package for education and data analysis. Palaeontol. Electron. 4:9.

Harris, P. T., Barrie, J. V., Conway, K. W., and Greene, H. G. (2013). Hanging canyons of Haida Gwaii, British Columbia, Canada: fault-control on submarine canyon geomorphology along active continental margins. Deep Sea Res. II 104, 83-92. doi: 10.1016/j.dsr2.2013.06.017

Harris, P. T., and Whiteway, T. (2011). Global distribution of large submarine canyons: geomorphic differences between active and passive continental margins. Mar. Geol. 285, 69-86. doi: 10.1016/j.margeo.2011.05.008

Henry, L. A., and Roberts, J. M. (2007). Biodiversity and ecological composition of macrobenthos on coldwater coral mounds and adjacent off-mound habitat in the bathyal Porcupine Seabight, NE Atlantic. . Deep Sea Res. Part I Oceanogr. Res. Pap. 54, 654-672. doi: 10.1016/j.dsr.2007.01.005

Henry, L. A., and Roberts, J. M. (2013). Recommendations for best practice in deepsea habitat classification: Bullimore et al. as a case study. ICES J. Mar. Sci. 71, 895-898. doi: 10.1093/icesjms/fst175

Henry, L. A., and Roberts, J. M. (2015). "Global biodiversity in cold-water coral reef ecosystems," in Marine Animal Forests: The Ecology of Benthic Biodiversity Hotspots, eds S. Rossi, L. Bramanti, A. Gori, and C. Orejas (Berlin: Springer), 1-21. doi: 10.1007/978-3-319-17001-5_6-1

Henry, L. A., Vad, J., Findlay, H. S., Murillo, J., Milligan, R., and Roberts, J. M. (2014). Environmental variability and biodiversity of megabenthos on the Hebrides Terrace Seamount (Northeast Atlantic). Sci. Rep. 4, 55-89.

Hogan, R. I., Hopkins, K., Wheeler, A. J., Allcock, A. L., and Yesson, C. (2019). Novel diversity in mitochondrial genomes of deep-sea Pennatulacea (Cnidaria: Anthozoa: Octocorallia). Mitochondrial DNA Part A 30, 764-777. doi: 10.1080/ 24701394.2019.1634699

Huang, Z., Nichol, S. L., Harris, P. T., and Caley, M. J. (2014). Classification of submarine canyons of the Australian continental margin. Mar. Geol. 357, 362-383. doi: 10.1016/j.margeo.2014.07.007

Huvenne, V. A., and Davies, J. S. (2014). Towards a new and integrated approach to submarine canyon research. Introduction. Deep Sea Res. Part II Top. Stud. Oceanogr. 104, 1-5. doi: 10.1016/j.dsr2.2013.09.012

Huvenne, V. A., Tyler, P. A., Masson, D. G., Fisher, E. H., Hauton, C., Huehnerbach, V., et al. (2011). A picture on the wall: innovative mapping reveals cold-water coral refuge in submarine canyon. PLoS One 6:e28755. doi: 10.1371/journal. pone.0028755

Huvenne, V. A. I., Bett, B. J., Masson, D. G., Le Bas, T. P., and Wheeler, A. J. (2016). Effectiveness of a deep sea cold-water coral Marine Protected Area, following eight years of fisheries closure. Biol. Conserv. 200, 60-69. doi: 10.1016/j.biocon. 2016.05.030

Jenness, J. (2002). Surface Areas and Ratios from Elevation Grid (surfgrids.avx) Extension for ArcView 3.x-version 1.2. Jenness enterprises. Available online at: http://www.jennessent.com/arcview/surface_areas.htm (accessed July 16, 2020).

Jonsson, L. G., Nilsson, P. G., Floruta, F., and Lundälv, T. (2004). Distributional patterns of macro-and megafauna associated with a reef of the cold-water coral Lophelia pertusa on the Swedish west coast. Mar. Ecol. Prog. Ser. 284, 163-171. doi: $10.3354 /$ meps 284163
Kaiser, S., and Barnes, D. K. (2008). Southern Ocean deep-sea biodiversity: sampling strategies and predicting responses to climate change. Clim. Res. 37, 165-179. doi: 10.3354/cr00761

Kenchington, E., Cogswell, A., MacIsaac, K., Beazley, L., Law, B., and Kenchington, T. (2014). Limited depth zonation among bathyal epibenthic megafauna of the Gully submarine canyon, northwest Atlantic. Deep Sea Res. II 104, 67-82. doi: 10.1016/j.dsr2.2013.08.016

Khripounoff, A., Caprais, J. C., Le Bruchec, J., Rodier, P., Noel, P., and Cathalot, C. (2014). Deep cold-water coral ecosystems in the Brittany submarine canyons (Northeast Atlantic): hydrodynamics, particle supply, respiration, and carbon cycling. Limnol. Oceanogr. 59, 87-98. doi: 10.4319/lo.2014.59.1.0087

Kiriakoulakis, K., Blackbird, S., Ingels, J., Vanreusel, A., and Wolff, G. A. (2011). Organic geochemistry of submarine canyons: the Portuguese Margin. Deep Sea Res. Part II Top. Stud. Oceanogr. 58, 2477-2488. doi: 10.1016/j.dsr2.2011. 04.010

Kiriakoulakis, K., Freiwald, A., Fisher, E., and Wolff, G. A. (2007). Organic matter quality and supply to deep-water coral/mound systems of the NW European Continental Margin. Int. J. Earth Sci. 96, 159-170. doi: 10.1007/s00531-0060078-6

Krishnamoorthy, K., and Thomson, J. (2002). Hypothesis testing about proportions in two finite populations. Am. Stat. 56, 215-222. doi: 10.1198/ 000313002164

Lampitt, R. S., Billett, D. S. M., and Rice, A. L. (1986). Biomass of the invertebrate megabenthos from 500 to $4100 \mathrm{~m}$ in the northeast Atlantic Ocean. Mar. Biol. 93, 69-81. doi: 10.1007/bf00428656

Leduc, D., Rowden, A. A., Nodder, S. D., Berkenbusch, K., Probert, P. K., and Hadfield, M. G. (2014). Unusually high food availability in Kaikoura Canyon linked to distinct deep-sea nematode community. Deep Sea Res. II 104, 310-318. doi: 10.1016/j.dsr2.2013.06.003

Levin, L. A., Etter, R. J., Rex, M. A., Gooday, A. J., Smith, C. R., Pineda, J., et al. (2001). Environmental influences on regional deep-sea species diversity. Annu. Rev. Ecol. Syst. 32, 51-93. doi: 10.1146/annurev.ecolsys.32.081501.114002

Lim, A., Kane, A., Arnaubec, A., and Wheeler, A. J. (2018). Seabed image acquisition and survey design for cold water coral mound characterisation. Mar. Geol. 395, 22-32. doi: 10.1016/j.margeo.2017.09.008

Lim, A., and Shipboard Party (2018). Controls of Cold-Water Coral Habitats in Submarine Canyons (CoCoHaCa II), survey (CE18011) of the Porcupine Bank Canyon, Cruise Report. Available online at: http://marinegeology.ucc. ie/wpcontent/uploads/sites/87/2018/08/Cruise-Report-CoCoHaCa-II.pdf (accessed August 20, 2018).

Lim, A., and Shipboard Party (2019). Monitoring Changes in Submarine Canyon Coral Habitats - Leg 1 (MoCha_Scan I), survey (CE19008) of the Porcupine Bank Canyon, Cruise Report. Available online at: http://marinegeology.ucc.ie/wpcontent/uploads/sites/87/2019/06/MoCha_SCan_Cruise_Report.pdf (accessed September 11, 2019).

Lim, A., Wheeler, A. J., and Arnaubec, A. (2017). High-resolution facies zonation within a cold-water coral mound: the case of the Piddington Mound, Porcupine Seabight, NE Atlantic. Mar. Geol. 390, 120-130. doi: 10.1016/j.margeo.2017. 06.009

Liu, C. S., Lundberg, N., Reed, D. L., and Huang, Y. L. (1993). Morphological and seismic characteristics of the Kaoping Submarine Canyon. Mar. Geol. 111, 93-108. doi: 10.1016/0025-3227(93)90190-7

Lo Iacono, C., Sulli, A., and Agate, M. (2014). Submarine canyons of north-western Sicily (Southern Tyrrhenian Sea): variability in morphology, sedimentary processes and evolution on a tectonically active margin. Deep Sea Res. II 104, 93-105. doi: 10.1016/j.dsr2.2013.06.018

Lueck, R., Laurent, L. S., and Moum, J. (2009). "Turbulence in the benthic boundary layer," in Encyclopedia of Ocean Sciences: Elements of Physical Oceanography, eds J. Steele, S. Thorpe, and K. Turekian (Cambridge, MA: Academic Press), 311-316.

Lysiak-Pastuszak, E., and Krysell, M. (2004). Chemical Measurements in the Baltic Sea: Guidelines on Quality Assurance. ICES Techniques in Marine Environmental Sciences, No. 35. Available online at: https://repository. oceanbestpractices.org/handle/11329/671 (accessed August 20, 2018).

Macdonald, T. A., Burd, B. J., Macdonald, V. I., and Van Roodselaar, A. (2010). Taxonomic and Feeding Guild Classification for the Marine Benthic Macroinvertebrates of the Strait of Georgia, British Columbia. Ottawa: Fisheries and Oceans Canada, 63. 
Martín, J., Palanques, A., Vitorino, J., Oliveira, A., and De Stigter, H. C. (2011). Near-bottom particulate matter dynamics in the Nazaré submarine canyon under calm and stormy conditions. Deep Sea Res. Part II Top. Stud. Oceanogr. 58, 2388-2400. doi: 10.1016/j.dsr2.2011.04.004

Martín, J., Puig, P., Palanques, A., and Ribó, M. (2014). Trawling-induced daily sediment resuspension in the flank of a Mediterranean submarine canyon. Deep Sea Res. Part II Top. Stud. Oceanogr. 104, 174-183. doi: 10.1016/j.dsr2.2013. 05.036

Massironi, C. (2016). Cold-Water Coral Bioconstructions from the Moira Mounds (NE Atlantic): Biodiversity and Species Distribution Pattern. Master's thesis, Università degli Studi di Milano, Milano MI.

Mazzini, A., Akhmetzhanov, A., Monteys, X., and Ivanov, M. (2012). The Porcupine Bank Canyon coral mounds: oceanographic and topographic steering of deep-water carbonate mound development and associated phosphatic deposition. Geomar. Lett. 32, 205-225. doi: 10.1007/s00367-0110257-8

McCave, I. N., Hall, I. R., Antia, A. N., Chou, L., Dehairs, F., Lampitt, R. S., et al. (2001). Distribution, composition and flux of particulate material over the European margin at 47-50 N. Deep Sea Res. Part II Top. Stud. Oceanogr. 48, 3107-3139. doi: 10.1016/s0967-0645(01)00034-0

McClain, C. R., and Barry, J. P. (2010). Habitat heterogeneity, disturbance, and productivity work in concert to regulate biodiversity in deep submarine canyons. Ecology 91, 964-976. doi: 10.1890/09-0087.1

Mienis, F., De Stigter, H. C., White, M., Duineveld, G., De Haas, H., and Van Weering, T. C. E. (2007). Hydrodynamic controls on cold-water coral growth and carbonate-mound development at the SW and SE Rockall Trough Margin, NE Atlantic Ocean. Deep Sea Res. Part I Oceanogr. Res. Pap. 54, 1655-1674. doi: 10.1016/j.dsr.2007.05.013

Miller, K. G., Browning, J. V., John Schmelz, W., Kopp, R. E., Mountain, G. S., and Wright, J. D. (2020). Cenozoic sea-level and cryospheric evolution from deep-sea geochemical and continental margin records. Sci. Adv. 6:eaaz1346. doi: $10.1126 /$ sciadv.aaz1346

Mordecai, G., Tyler, P., Masson, D. G., and Huvenne, V. A. I. (2011). Litter in submarine canyons off the west coast of Portugal. Deep Sea Res. Part II 58, 2489-2496. doi: 10.1016/j.dsr2.2011.08.009

Morris, K. J., Tyler, P. A., Masson, D. G., Huvenne, V. I., and Rogers, A. D. (2013). Distribution of cold-water corals in the Whittard Canyon, NE Atlantic Ocean. Deep Sea Res. Part II Top. Stud. Oceanogr. 92, 136-144. doi: 10.1016/j.dsr2. 2013.03.036

Mortensen, P. B., and Buhl-Mortensen, L. (2004). Distribution of deep-water gorgonian corals in relation to benthic habitat features in the Northeast Channel (Atlantic Canada). Mar. Biol. 144, 1223-1238. doi: 10.1007/s00227-003-1280-8

Mortensen, P. B., and Fosså, J. H. (2006). "Species diversity and spatial distribution of invertebrates on deep-water Lophelia reefs in Norway," in Proceedings of 10th International Coral Reef Symposium, Okinawa, 1849-1868.

Naumann, M. S., Orejas, C., and Ferrier-Pagès, C. (2014). Species-specific physiological response by the cold-water corals Lophelia pertusa and Madrepora oculata to variations within their natural temperature range. Deep Sea Res. Part II Top. Stud. Oceanogr. 99, 36-41. doi: 10.1016/j.dsr2.2013.05.025

Oksanen, J. (2011). Multivariate analysis of ecological communities in R: vegan tutorial. R Package Version 1, 1-43. doi: 10.1007/978-94-009-3135-0_1

Oksanen, J., Blanchet, F. G., Kindt, R., Legendre, P., Minchin, P. R., O'hara, R. B., et al. (2014). Package 'vegan'. Community ecology package, version, 2.2-0. Available online at: http://CRAN.Rproject.org/package=vegan (accessed January 2, 2020).

Orejas, C., Gori, A., and Gili, J. M. (2008). Growth rates of live Lophelia pertusa and Madrepora oculata from the Mediterranean Sea maintained in aquaria. Coral Reefs 27, 255-255. doi: 10.1007/s00338-007-0350-7

Orejas, C., Gori, A., Lo Iacono, C., Puig, P., Gili, J.-M., and Dale, M. R. T. (2009). Cold-water corals in the Cap de Creus canyon, northwestern Mediterranean: spatial distribution, density and anthropogenic impact. Mar. Ecol. Prog. Ser. 397, 37-51. doi: 10.3354/meps08314

Paterson, G. L., Glover, A. G., Cunha, M. R., Neal, L., de Stigter, H. C., Kiriakoulakis, K., et al. (2011). Disturbance, productivity and diversity in deep-sea canyons: a worm's eye view. Deep Sea Res. Part II Top. Stud. Oceanogr. 58, 2448-2460. doi: 10.1016/j.dsr2.2011.04.008

Pfannkuche, O., Bannert, B., Beck, T., Beuck, L., Dullo, W. C., Flögel, S., et al. (2004). "Geo-biological investigations on azooxanthellate cold-water coral reefs on the carbonate mounds along the celtic continental slope, Lisbon" in Cruise No. 61, Leg 1 (2004). DFG-Senatskommission fur Ozeanographie (Bremen). doi: $10.2312 / \mathrm{cr} \_\mathrm{m} 61$

Pielou, E. C. (1966). The measurement of diversity in different types of biological collections. J. Theor. Biol. 13, 131-144. doi: 10.1016/0022-5193(66)90013-0

Puig, P., and Gili, J. M. (2019). "27 Submarine Canyons in the Mediterranean: a Shelter for Cold-Water Corals," in Mediterranean Cold-Water Corals: Past, Present and Future, eds C. Orejas and C. Jiménez (Cham: Springer), 285-289. doi: 10.1007/978-3-319-91608-8_27

Puig, P., Greenan, B. J. W., Li, M. Z., Prescott, R. H., and Piper, D. J. W. (2013). Sediment transport processes at the head of Halibut Canyon, eastern Canada margin: an interplay between internal tides and dense shelf-water cascading. Mar. Geol. 341, 14-28. doi: 10.1016/j.margeo.2013.05.004

Puig, P., Palanques, A., and Martín, J. (2014). Contemporary sediment-transport processes in submarine canyons. Annu. Rev. Mar. Sci. 6, 5.1-5.25.

Quattrini, A. M., Ross, S. W., Carlson, M. C., and Nizinski, M. S. (2012). Megafaunal-habitat associations at a deep-sea coral mound off North Carolina, USA. Mar. Biol. 159, 1079-1094. doi: 10.1007/s00227-012-1888-7

R Core Development Team (2014). R: A Language and Environment for Statistical Computing. Vienna: R Foundation for Statistical Computing.

Ramirez-Llodra, E., Company, J. B., Sarda, F., and Rotllant, G. (2010). Megabenthic diversity patterns and community structure of the Blanes submarine canyon and adjacent slope in the Northwestern Mediterranean: a human overprint? Mar. Ecol. 31, 167-182. doi: 10.1111/j.1439-0485.2009.00336.x

Robert, K., Jones, D. O., and Huvenne, V. A. (2014). Megafaunal distribution and biodiversity in a heterogeneous landscape: the iceberg-scoured Rockall Bank, NE Atlantic. Mar. Ecol. Prog. Ser. 501, 67-88. doi: 10.3354/meps 10677

Roberts, J. M., Wheeler, A. J., and Freiwald, A. (2006). Reefs of the deep: the biology and geology of cold water coral ecosystems. Science 312, 543-547. doi: 10.1126/science.1119861

Rosenzweig, M. L. (1995). Species Diversity in Space and Time. Cambridge: Cambridge University Press.

Sawada, M. (1999). ROOKCASE: an Excel 97/2000 Visual Basic (VB) Add-in for Exploring Global and Local Spatial Autocorrelation. Bull. Ecol. Soc. Am. 80, 231-234.

Scharf, I., Nulman, E., Ovadia, O., and Bouskila, A. (2006). Efficiency evaluation of two competing foraging modes under different conditions. Am. Nat. 168, 350-357. doi: $10.2307 / 3844693$

Schlacher, T. A., Schlacher-Hoenlinger, M. A., Williams, A., Althaus, F., Hooper, J. N., and Kloser, R. (2007). Richness and distribution of sponge megabenthos in continental margin canyons off southeastern Australia. Mar. Ecol. Prog. Ser. 340, 73-88. doi: 10.3354/meps340073

Schlining, K., von Thun, S., Kuhnz, L., Schlining, B., Lundsten, L., Stout, N. J., et al. (2013). Debris in the deep: using a 22-year video annotation database to survey marine litter in Monterey Canyon, central California, USA. Deep Sea Res. Part I Oceanogr. Res. Pap. 79, 96-105. doi: 10.1016/j.dsr.2013.05.006

Shan, S., Sheng, J., and Greenan, B. J. W. (2014). Physical processes affecting circulation and hydrography in the Sable Gully of Nova Scotia. Deep Sea Res. II 104, 35-50. doi: 10.1016/j.dsr2.2013.06.019

Shannon, C. E. (1948). A mathematical theory of communication. Bell Syst. Tech. J. 27, 379-423.

Shannon, P. M. (1991). The development of Irish offshore sedimentary basins. J. Geol. Soc. 148, 181-189. doi: 10.1144/gsigs.148.1.0181

Shannon, P. M., McDonnell, A., and Bailey, W. R. (2007). The evolution of the Porcupine and Rockall basins, offshore Ireland: the geological template for carbonate mound development. Int. J. Earth Sci. 96, 21-35. doi: 10.1007/ s00531-006-0081-y

Shepard, F. P. (1972). Submarine canyons. Earth Sci. Rev. 8, 1-12.

Smith, C. R., Jumars, P. A., and DeMaster, D. J. (1986). In situ studies of megafaunal mounds indicate rapid sediment turnover and community response at the deep-sea floor. Nature 323, 251-253. doi: 10.1038/323251a0

Stewart, H. A., Davies, J. S., Guinan, J. C., and Howell, K. L. (2014). The Dangeard and Explorer Canyons, South-West Approaches, UK: geology, sedimentology and newly discovered cold-water coral mini-mounds. Deep Sea Res. II 104, 230-244. doi: 10.1016/j.dsr2.2013.08.018

Strickland, J. D. H., and Parsons, T. R. (1972). A Practical Handbook of Seawater Analysis, 2nd Edn, Vol. 167. Ottawa: Fisheries Research Board of Canada, 310. 
Ter Braak, C. J. (1986). Canonical correspondence analysis: a new eigenvector technique for multivariate direct gradient analysis. Ecology 67, 1167-1179. doi: $10.2307 / 1938672$

Thiel, M., and Watling, L. (2015). Lifestyles and Feeding Biology (Vol. 2). Natural History of the Crustac. Oxford: Oxford University Press.

Trotter, J. A., Pattiaratchi, C., Montagna, P., Taviani, M., Falter, J., Thresher, R., et al. (2019). First ROV exploration of the Perth Canyon: canyon setting, faunal observations, and anthropogenic impacts. Front. Mar. Sci. 6:173. doi: 10.3389/ fmars.2019.00173

Tubau, X., Canals, M., Lastras, G., Rayo, X., Rivera, J., and Amblas, D. (2015). Marine litter on the floor of deep submarine canyons of the Northwestern Mediterranean Sea: the role of hydrodynamic processes. Prog. Oceanogr. 134, 379-403. doi: 10.1016/j.pocean.2015.03.013

van den Beld, I. M., Bourillet, J. F., Arnaud-Haond, S., De Chambure, L., Davies, J. S., Guillaumont, B., et al. (2017). Cold-water coral habitats in submarine canyons of the Bay of Biscay. Front. Mar. Sci. 4:118. doi: 10.3389/fmars.2017. 00118

van Weering, T. C. E., de Haas, H., Akhmetzanov, A. M., and Kenyon, N. H. (2003). "Giant carbonate mounds along the porcupine and SW Rockall Trough Margins," in European Margin Sediment Dynamics, eds J. Mienert and P. Weaver (Heidelberg: Springer).

Vertino, A., Savini, A., Rosso, A., Di Geronimo, I., Mastrototaro, F., Sanfilippo, R., et al. (2010). Benthic habitat characterization and distribution from two representative sites of the deep-water SML Coral Province (Mediterranean). Deep Sea Res. Part II Top. Stud. Oceanogr. 57, 380-396. doi: 10.1016/j.dsr2. 2009.08.023

Vetter, E. W., Smith, C. R., and De Leo, F. C. (2010). Hawaiian hotspots: enhanced megafaunal abundance and diversity in submarine canyons on the oceanic islands of Hawaii. Mar. Ecol. 31, 183-199. doi: 10.1111/j.1439-0485.2009. 00351.x

Volkov, D. L., Lee, S. K., Landerer, F. W., and Lumpkin, R. (2017). Decade-long deep-ocean warming detected in the subtropical South Pacific. Geophys. Res. Lett. 44, 927-936. doi: 10.1002/2016gl071661

Wheeler, A. J., Beck, T., Thiede, J., Klages, M., Grehan, A., Monteys, F. X., et al. (2005). "Deep-water coral mounds on the Porcupine Bank, Irish Margin: preliminary results from the Polarstern ARK-XIX/3a ROV cruise," in ColdWater Corals and Ecosystems. Erlangen Earth Conference Series, eds A. Freiwald and J. M. Roberts (Heidelberg: Springer).

Wheeler, A. J., Beyer, A., Freiwald, A., De Haas, H., Huvenne, V. A. I., Kozachenko, M., et al. (2007). Morphology and environment of cold-water coral carbonate mounds on the NW European margin. Int. J. Earth Sci. 96, 37-56. doi: 10.1007/ s00531-006-0130-6

Wheeler, A. J., and Shipboard Party (2017). Controls of Cold-Water Coral Habitats in Submarine Canyons (CoCoHaCa I) survey (RH17002) of the Porcupine Bank Canyon, Cruise Report. Available online at: http://marinegeology.ucc.ie/mrluke-o-reilly/ (accessed May 28, 2018).

Wienberg, C., Beuck, L., Heidkamp, S., Hebbeln, D., Freiwald, A., Pfannkuche, O., et al. (2008). Franken Mound: facies and biocoenoses on a newly discovered "carbonate mound" on the western Rockall Bank, NE Atlantic. Facies 54, 1-24. doi: 10.1007/s10347-007-0118-0

Wilson, A. M., Kiriakoulakis, K., Raine, R., Gerritsen, H. D., Blackbird, S., Allcock, A. L., et al. (2015). Anthropogenic influence on sediment transport in the Whittard Canyon, NE Atlantic. Mar. Pollut. Bull. 101, 320-329. doi: 10.1016/j. marpolbul.2015.10.067

Young, T. P. (2000). Restoration ecology and conservation biology. Biol. Conserv. 92, 73-83. doi: 10.1016/s0006-3207(99) 00057-9

Conflict of Interest: The authors declare that the research was conducted in the absence of any commercial or financial relationships that could be construed as a potential conflict of interest.

Copyright (C) 2020 Appah, Lim, Harris, O'Riordan, O'Reilly and Wheeler. This is an open-access article distributed under the terms of the Creative Commons Attribution License (CC BY). The use, distribution or reproduction in other forums is permitted, provided the original author(s) and the copyright owner(s) are credited and that the original publication in this journal is cited, in accordance with accepted academic practice. No use, distribution or reproduction is permitted which does not comply with these terms. 